\section{CEM DİLÇINN}

\section{Stilistik Açıdan "Öncelemeler" ve Fuzulí'nin Şiirlerinde "Yüklem Öncelemesi"}

Foregrounding in Stylistic View and Predicate

Foregrounding in the Poems of Fuzulî
Ö Z E T

Herhangi bir cümle öğesine belli bir amaçla cümlede ilk strayı vermek sözlü ve yazll anlatımda önemli bir dil olayıdır. Devrikleme olarak adlandirilan bu dil olayı, manzum ve mensur bütün metinlerde karşımıza çıkar. Cümle öğelerinin bu türlü kullanılması, stilistik açıdan bakıldığında duygusal ve düşünsel çok önemli sonuçlar doğurur. Bu kullanımlarm ayrıca, cümlenin anlamın belli bir yönde vurgulamak ve güçlendirmek açısından da çok büyük bir etkisi vardır. Böyle kullanımların örneklerine Türk edebiyatının her dönem şiirinde çok sık rastlanır. Bu yazıda divan şiirinin büyük ustalarmdan Fuzulīnin şiirlerinde özellikle yüklemin beyit ya da dize başlarnda kullanılmasina ilişkin örnekler üzerinde durulmuş, bunların değerlendirilmesi yapılmış ve başka divan şairlerinin şiirlerinden de konuyu pekiştirmek amactyla bazı örnekler verilmiştir.

A N A H T A R K E L İ M E L E R

Stilistik, devrikleme, önceleme, divan şiiri, Fuzulî.
A B S T R A C T

To pleace a certain item in the beginning of a sentence for a certain purpose is important fact of language in both verbal and written expressions. This is called anastrophe and it can be observed in all poems and texts. Such expressions also have a great effect emphasizing and intensifying the meaning of the sentence in a certain way. Examples for this use are widely observed in all types of poems in all periods of Turkish literature. This article focuses on the examples in which the predicate is used in the beginning of the verse or line in the poems of Fuzuli, who is one of the greatest masters of Ottoman poetry and some other examples from other Ottoman poets are provided as well.

K E Y W O R D S

Stylistics, anastrope, foregrounding, Ottoman poetry, Fuzuli.

Öncelemeler, yazılı ve sözlü anlatımda önemli bir dil olayıdır. Buna bağlı olarak nazımda ve nesirde kullanılış biçimlerinin doğurduğu sonuçlara göre, stilistik açıdan duygusal ve düşünsel etkiler yaratan türlü söz ve anlam sanatları düzeyinde bir görünüm kazanmış olarak karşımıza çıkar. Öncelemelerin şiir dilinin oluşturulmasında kurgusal yöntemler açısından çok önemli bir yeri vardır. Şairler öncelemeleri, yeni, değişik, özgün, benzerlerinden ayrı ya da öncekilerden daha güzel bir

\footnotetext{
"Prof. Dr., Hacettepe Üniversitesi Edebiyat Fakültesi Türk Dili ve Edebiyatı Bölümü,
} Ankara. 
anlam ve söz yapısı içerisinde kendilerine özgü ölçütlerle seçtikleri kelimelerle sanatlarının ve üslûplarının temel bir gereği ve özelliği olarak uygularlar. Bu nedenle, bir şiirin, bir beytin ya da bir dizenin hangi sözle başlayacağ1 dilbilgisi kurallarına göre değil, şiir sanatının inceliklerine göre belirlenir. Bir şair ya da yazar kişisel, bilgisel, çă̆rışımcı, inandırıcı, mantıksal, duygusal, sanatsal amaçlardan biri ya da birkaçı doğrultusunda dil gereçlerini kullanır (Özünlü 1997: 2-3), söz seçimi yapar ve bunlara bağlı olarak da en uygun bir cümle öğesini "önceler". Stilistik çalışmalarında dilin kullanımı, buna bağlı olarak da şiir dilinin oluşması açısından belirleyici bir ölçüt niteliğinde olan öncelemeler, koşutlukların, yinelemelerin, sapmaların yanında devriklemelerin (anastrophe) de ortaya çıkmasında önemli bir etkendir. Bu yönden bakıldığında divan ve mesneviler, şiir dilinde stilistik açısından öncelemelerin yerini ve önemini bütün yönleriyle örneklendirebilecek zenginlikte bir kaynaktır.

Şiirsel dilin oluşmasında, şiirsel yapının kurulmasında devriklemeler, başka bir deyişle her çeşit öncelemeler, divan şiirinde bir "söz mimarlığı" niteliğindedir. Şiirsel anlatıma uygun "cümle mimarisi", nazım söz diziminde "cümleyi inşa etmek" açısından çok önemlidir. Şiirin pek çok tanımı arasında, "dili kullanma sanatı" biçiminde yapılan tanımı, şiire somut bir görünüm ve nitelik kazandırmıştır. Bu nedenle, sözü şiir yapan gizil ve etkin güçlerin arasında öncelemelerin özel bir yerinin olduğunu söylemek hiç de yanlış olmaz.

Dilbilgisi kitaplarının kimilerinde, nazımdaki devriklemelerin vezin, kafiye, redif gibi "zorunluluk"lar nedeniyle yanlış sayılmayarak hoş görüldüğü ya da doğal karşılandığı değerlendirmeleri yapılmıştır. Bu türlü görüşler belli bir oranda doğru olabilirse de devriklemeler, sanatkâr şairler elinde estetik bir kaygıyla bilinçli olarak yapılmış düzenlemelerdir. Pek çok dize vezin ve kafiyesi bozulmadan farklı söz düzenlemeleri ve kelime dizilişleri içerisinde söylenebilirse de böyle durumlarda anlam etkisinin ve duygu coşkusunun büyük ölçüde yok olduğu hemen görülür. Bir beyit nesre çevrildiği yani kurallı cümle durumuna getirildiği zaman, beytin aslındaki devrikliğin yarattığı şiirsel söylemin canlılığı, anlamsal etkinin akışkanlığı hemen kaybolur; geriye de yalnızca durağan, donuk, kuru bir cümle yargısı kalır. Bu nedenle nazımda devrikleme ya da her türlü önceleme bir "zorunluluk" değil, uygulama açısından, 
eski deyimle söylersek "eşyanın tabiatına aykırı olmayan" bir "gereklilik"tir. Bu durumda vezinli, kafiyeli, redifli şiirler için bir "zorunluluk" olarak değerlendirilen önceleme, vezinsiz, kafiyesiz, redifsiz şiirler için bir "doğallık" gibi değerlendiriliyor demektir. Bu tür şiir alanında ürün verenler devriklemenin açılımlarından yararlanacak, vezinli, kafiyeli, redifli şiir söyleyen şairler ise bu açlımlardan uzak kalacaklar; böyle bir durum söz konusu olamaz. Ben, kimi dilbilgisi kitaplarındaki bu türlü değerlendirmeleri bir yönüyle, Türk edebiyatının her dönem şairleri ve bunların şiirleri üzerinde gerektiği biçimde ve yeterli ölçüde stilistik çalışmaların yapılmadığı olgusuna bağlıyorum. Böyle çalışmaların yapılmamış olması, divan ve halk şiirinde ya da benzeri nazım türlerinde devriklemenin sanki "manzum" olmanın bir gereği imiş gibi algılanması, dolayısıyla da doğal kabul edilmesi sonucunu doğurmuştur.

Devrikleme sonucunda nesirde ya da nazımda ortaya çıkan cümlelerin, "kuralsız, yanlış, bozuk..." sıfatlarıyla nitelendirilmesi doğru değildir. Devrik cümlelerde öğeler, anlama nasıl bir yön verilmek isteniyor ya da anlam nasıl bir önem sırası gerektiriyorsa ona göre söz diziminde yerini alır. Söz diziminde baş yer, sözün ve konunun ekseni durumunda olan öğe içindir, cümlede görevi ne olursa olsun o kelime öne alınır (Dizdaroğlu 1976: 250-252). Bu nedenle, düşünce ve duyguların niceliği ve niteliği sözlü ve yazılı anlatımda devrikleme ve öncelemeleri bir anlamda zorunlu kılmaktadır.

Devrik cümleler, kurallı cümlelerden daha vurgulu, tonlu ve dokunaklı söylenmeye elverişlidir. Yerinde kullanılınca da kurallı cümleden daha derin, daha zengin duygular ve imgeler taşıyabilmektedir. Anlatım gücünü her şeyden üstün sayan anlambilimcilere göre, cümlenin güzelliği geleneksel kurallara uygunlukta değil anlatıma sindirilen duygu, imge değeriyle ve sözlerin örülüşlerinden ve kelimelerin dizilişlerinden doğan ses güzelliğiyle ölçülür. Böyle bir devrik cümle, kurallı cümleye çevrilince, sözlerin örgüsüne ve kelimelerin dizilişine sinmiş duygu ve imge değerleri ile cümledeki coşkunluk ve söylemdeki tat ortadan kalkar (Gencan 1979: 116).

Nesirde devrik cümle kullanılması da her çeşit öncelemenin yarattığ1 semantik ve stilistik etkiden, algılama ve çağrışım zenginliğinden yararlanmak içindir. Devrikleme ve öncelemelerin bir işlevi de, metin içeri- 
sinde arka planda görünen ya da bulunan bir öğeyi ön plana çekerek duygusal ve düşünsel yönden ona bir etkenlik kazandırmaktır. Bu nedenle konuşma dilinde, atasözleri ve deyimlerde, tiyatro yapitlarında, roman ve hikâyelerde çok çeşitli ve canlı örneklerini gördügümüz öncelemelerin dilin anlatım gücünü artırmada yüklendikleri işlev gerçekten küçümsenemez ölçüdedir.

Türkçe'nin özleşmesi konusunda büyük çabalar harcamış, Türk edebiyatına deneme ve eleştiri alanlarında önemli katkılarda bulunmuş olan Nurullah Ataç, bu konuda çok eleştirilmesine karşın, kendine özgü devriklemeler ve dolayısıyla öncelemelerle Türk dilini kullanmada nesri nazma yaklaştırarak yazı dilinin anlatım kalıpları içerisinde tekdüzeleşmiş söz dizimine kıvrak bir akıcılık ve coşkulu bir şiirsellik getirmiştir. Ataç'ın, denemelerinde böyle bir dil kullanmasının, üslûbunu kendi dil ve sanat anlayışı doğrultusunda özgüleştirmesinin, o yıllarda "öz Türkçe" terimiyle nitelendirilen yeni türetilmiş, eski metinlerden aktarılarak canlandırılmış ya da Anadolu ağızlarından alınarak genelleştirilmiş pek çok kelimenin, yazarlar, şairler, bilim adamları ve geniş halk kitlelerince benimsenmesi konusunda çok büyük etkisi olmuştur.

Yüzyıllardan beri kullandığımız atasözleri ve deyimler arasında devrik yapıda pek çok vezinli vezinsiz, kafiyeli kafiyesiz örnek bulunmaktadır. Bilindiği gibi bu türlü sözlerin büyük çoğunluğu kalıplaşmış bir söz yapısındadır, değiştirilemez. Bunların söz yapıları, kelime dizilişleri değiştirildiği durumlarda ise, kullanımda geçerli olan ve herkesçe bilinen anlamları kaybolur, anlaşmada, iletişimde güçlüklerle karşılaşılır. Örneğin, 'karışık ve içinden çıkılamaz durumdaki bir iş' için kullanılan "ayıkla pirincin taşını" deyimi, kurallı cümle olarak "pirincin taşını ayıkla" biçiminde söylenirse, akla hemen "pilav yapmak için bir aşçının yamağına verdiği emir" gelir. 'Beklenmedik, uygunsuz bir durum'da söylenilen "öp babanın elini" deyimi de, "babanın elini öp" biçimine çevrildiğinde yine emir olarak, ancak bir çocuğa babasına saygısını göstermesi konusunda söylenebilir.

Divan şiirinde olduğu gibi halk şiirinde ve daha sonraki dönemlerin şiirinde de her tür nazım biçimiyle söylenmiş, kafiye ve redifi çekimli eylem olan pek çok örnek vardır. Ancak kafiyesi, kafiye kurallarının ağır basması nedeniyle ad soylu kelimelerle söylenmiş şiirler daha çoktur. 
Böyle durumlarda redif olarak daha yoğunlukla çekimli eylemler kullanılmıştır. Ad soylu bir kelimeyle kafiye ya da redifi kurulmuş bir şiirde (kaside ve gazelde), bir zorunluluk olmamakla birlikte kendiliğinden yüklem öncelemesine doğrudan uygun bir ortam hazırlanmış olmaktadır. Ancak, büyük şairler bu hazır ortamı, şiir sanatının gerektirdiği ölçütler içerisinde kullanmıştır. Kafiye ve redifin çekimli bir eylem olarak kullanıldığ1 durumlarda, yani en azından yüklemi sonda olan bir cümle yapısı taşıyan bir beyitte de gelişi güzel bir "önceleme yapıldığına" pek rastlanmaz. Şairlerin, vezin zorunluluğu gibi nedenlerle şiirsel söylemi bir yana koydukları, sanat kaygısından uzaklaştıkları, dizenin, beytin söz düzenini ve anlam yapısını önemsemeyip savsakladıkları sıkça görülen bir durum değildir. Böyle durumlarda şairler, yer yer o şiire özgü bir takım önceleme kalıpları oluşturarak ya da divan şiirinin bu yoldaki kalıplaşmış uygulamalarını kendi sanatı açısından özelleştirerek gerçekten çok güzel önceleme örnekleri ortaya koymuşlardır.

Öncelemelerde beytin ya da dizenin en başında yer alan kelimenin, yalnızca o beytin mazmununa özel, o beytin anlamına özgü görevini değerlendirmenin yanında, bu ilk sözden ya da cümle öğesinden sonra gelen sözlerin de üzerinde durulması çoğu zaman gerekebilir, hatta zorunlu da olabilir. Çünkü öncelenen sözden geriye doğru gidildikçe dizede ya da beyitte birbirine bağlı, zincirleme olarak anlamı geliştiren, duygu ve düşüncenin boyutlarını genişleten 2. ve 3. derecede görev üstlenmiş cümle öğeleri de mutlaka vardır.

Bu konuları örneklendirebilmek için Fuzulî́nin -ân eyler ve Nef'î́nin yine aynı kafiye ve 3 . tekil kişi çekiminde bir eylemin redif olarak seçildiği -ân virür kasidelerinin kimi beyitleri üzerinde çok kısa olarak durmak istiyorum. Nazım söz dizimi açısından yüklemin beytin sonunda olmasının yani kasidenin ya da gazelin redifinin çekimli bir eylem olmasının öncelemeler açısından şairleri pek fazla etkilemediği bu kısa değerlendirme doğrultusunda açıkça görülecektir.

Fuzulî’nin Kazasker Kadir Çelebi için söylediği kasidenin (s. 98-101) redifi "eyler" çekimli eylemidir. 45 beyit olan bu Kaside'sinde Fuzulî, sözdizimsel işlev açısından büyük bir önemi olmayan bir iki kullanım dışında yüklem öncelemesi yapmamıştır. Bunun karşılığında başka öncelemelerle şiirine etkileyici bir söz düzeni ve cümle yapısı kazandırmıştır. 
Kaside'nin kimi beyitlerinde, cümlelerin "belirtili nesneleri" nin öncelenmesi, "baharın gelişi"yle "bahçe" nin "okul"a, "çiçekler"in de "öğrenciler"e benzetilerek yapılan okul/ders/öğretmen/öğrenci ortamının somut bir canlılık içerisinde sanki renkli bir tablo gibi algılanması yolunu açmıştır. Şu beyitle (3. beyit) Fuzulî, "okul istiaresi"ni belirtir:

Yine pîr-i felek etfâl-i reyâhîni yı̆̆up

Feyz-i ta'lîm ile bustânı debistân eyler'

Aşağıda örnekler arasından seçilmiş 2 beytin (5. ve 6. beyitler) dizelerinde "gonca, lâle, sünbül, sûsen" gibi, cümlelerin belirtili nesnesi olan çiçek adları öncelenerek dikkatler bu sözler üzerine çekilmiş ve bu çiçeklerin "öğrenci" rolünde olmaları nedeniyle özelliklerine uyan hangi "ders"lerle uğraştıkları arka arkaya sıralanarak belirtilmiştir:

Gonceyi metn-i metâli'de idüp ukde-güşây

Lâleyi şerh-i tavâli'de sebak-hân eyler

Sünbüli ilm-i İlâhî'de kılup mûy-şikâf

Sûseni bahs-i riyâzîde sühan-dân eyler

Kaside'nin nesip bölümünde geçen başka türdeki öncelemeler de "okul istiaresi"ni pekiştirici niteliktedir. Bunların dışında Kaside'de, aşağ1daki beyitte (17. beyit) olduğu gibi, tasavvufî mecazlara göndermelerle başka güzel "nesne öncelemeleri" de yapılmıştır:

Katreyi müddet ilen muttasıl-1 bahr kılur

Zerreyi vâsıl-ı hur-şîd-i dırahşân eyler

Aynı Kaside'nin şu beytinde de (16. beyit) Fuzulî, dizede ikinci s1rada yer verdiği "daş" ve "su" nesnelerinden önce, "daşın la'l" ve "suyun lü'lü"ye dönüşmesinde etken olan "uzun bir bekleme ve zaman geçmesi" sürecini vurgulamak için "intizâr" ve "rûzgâr" sözlerini önceleyerek dikkatleri bu kavramlar üzerine çekmeyi amaçlamıştır:

\footnotetext{
${ }^{1}$ Fuzulî̀ye ilişkin olarak verilen beyitlerdeki sayfa numaraları için TD kısaltmasıyla gösterilen şu esere bakılmalıdır: Fuzûlî, Türkçe Divan, (Haz. Kenan Akyüz, Süheyl Beken, Sedit Yüksel, Müjgân Cunbur), Türkiye İş Bankası Kültür Yay., Ankara 1958.
} 
İntizâr ile daşı la'1 kılup reng virür

Rûzgâr ile suyı lü'lü'-i galtân eyler

Nef'î de Sultan I. Ahmet'e sunduğu ve nesip bölümüne "fahriye" ile başladığ1 Kaside'sinin (Dîvân 1252: Kas. s. 7-9) ilk 7 beytinde, şairlik yeteneğini, şiir söylemedeki düzeyini ve gücünü, türlü abartılı imgelerle süsleyerek belli söyleyiş kalıpları içerisinde birbirini destekleyen beyitlerde şöyle anlatır:

1 Her ma'ni-i latîf ki cândan nişân virür

Ta'bîr idince tab'um anı nazma cân virür

2 Her nazm-1 dil-firîb ki benden sudûr ider

Lafzı cemâl-i şâhid-i ma'nâya ân virür

3 Her nükte-i hafî ki kelâmumda derc olur Mazmûnı dest-i âleme bir dâstân virür

$4 \mathrm{Ol}$ sihr-sâz-1 mu'cize-gûyum ki nutkumun Feyzi devât $u$ kilke zebân $u$ dehân virür

5 Ol nâzım-1 leâli-i nazmum ki şi' rümün Reşki cemâda tab'-1 cevâhir-feşân virür

6 Pâkîze-gûy-1 nâdire-sencüm ki her sözüm Şeh-nâme-i belâgata hüsn-i beyân virür

7 Vassâf-1 Muhteşem-sühanem kim kasâidüm Şâhân-1 Cem-şükûh-1 cihân-bâna şân virür

$\mathrm{Bu}$ beyitlerdeki söz ve anlatım kalıplarını sergilemeye geçmeden önce, Kaside'nin redifi olan "virür" yükleminin özelliğinden ötürü, 59 beyitlik bu Kaside'nin düz tümleç kullanılan yalnızca 5-6 beytinin dışındaki öteki beyitlerinde yönelmeli tümleçler (-a/-e) kullanıldığını belirtmek yararlı olacaktır. Bu durum genellikle -e'li tümleç alan "vermek" eyleminden ileri gelmektedir. Başka bir yönden bu olguya bakıldığında, şairin bu eylemden dolayı zorunlu olarak yönelmeli tümleçleri anlatımına temel yaptığ1 ve bu tümleçlere dayanan cümleler kurduğu söylenebilir.²

\footnotetext{
${ }^{2}$ Fuzulî́nin yukarıdaki Kazasker Kadir Çelebi için söylediği "eyler" redifli kasidesinin pek çok beytinde cümleler, bu yüklem nedeniyle belirtili nesnelerle (belirtme durumunda tümleç, -i'li tümleç) kurulmuştur.
} 
$\mathrm{Bu}$ zorunluluk, şairin özgürlüğünü bir yönden kısıtlıyor da olsa, bir yönden de "tab'ını" yaratıcılık açısından zor bir alanda sınamasına olanak tanımaktadır. Zaten şairler böyle zor alanlara ne oranda açılırlarsa o oranda ortaya güzel ve ilginç söylemler koydukları da açık bir gerçektir.

Yukarıdaki 7 beyitten, 1-3., 4-5. ve 6-7. beyitlerin kendi aralarında ortak bir sözdizimsel yapı içerisinde söylendiği açıkça görülmektedir. Bu beyitlerin 1 . dizeleri ve 2 . dizeleri, birbirlerine göre belli bir koşutluk içerisinde ya da aynı söz kalıbıyla söylenmiş gibi görünse de, bu kalıpların içi değişik düşünce ve imgelerle doldurulmuştur. Bunlar ve aşağıda verilen yinelemeli önceleme ve sonlamalar şiire, bir müzik yapıtındaki ritim gibi, belli aralıklarla o bestede yinelenen ezgiler gibi bir ses ve söz uyumu kazandırmakta, ayrıca kulakta da kalıcı bir etki bırakmaktadır. Bunun yanı sıra asıl önemlisi de söz konusu değişik önceleme ve sonlamalar, söyleyişe bir çağrışım zenginliği katmakta, soyut kavramlara bir takım somut boyutlar (somutlaştırma) getirmekte, konuya bir renklilik, genişlik ve derinlik kazandırmaktadır. Bu 7 beytin 1. dizelerinin başında şiir/şair kavramları açısından birbirine çok yakın bir söz kuruluşu içerisinde sırasıyla şu öncelemeler yapılmıştır. Bunlardan 1-3., 4-5. ve 6-7. beyitler bu söz kuruluşları yönünden kendi aralarında koşutluk göstermektedir:

1. by. Her ma'ni-i ... ki...

2. by. Her nazm-1 ... ki...

3. by. Her nükte-i ... ki...

4. by. Ol sihr-sâz-1 ... -um ki...

5. by. Ol nâzım-1 ... -um ki...

6. by. Pâkîze-gûy-1 ... -um ki...

7. by. Vassâf-1 ... -um kim...

Bu öncelemelerin ilk üçündeki (1-3. by.) "her" sıfatı, '-in hepsi' anlamıyla şairin söylediği ya da şiirlerine konu ettiği "sözlerin tümü"nü, "bütün"ünü, "hepsi"ni kapsayan bir yaygınlık durumunu anlatmaktadır. 4-5. beyitlerdeki "ol" zamiri de, 'öyle, o denli, o derece' anlamlarıla Nef'î́nin şairliğine gönderme yapmaktadır. Kısaca bu "her" ve "ol" sözleri, yinelemenin de etkisiyle önüne getirildikleri adın ya da kavramın anlamını ve işlevini abartma amacıyla öncelenmiştir. 6-7. beyitlerde de 
İran'ın ünlü eserlerine ve büyük şairlerine göndermeler yapılarak Nef'î́nin şiiri ve şairliği sanki söz götürmez bir kesinlik içerisinde tanımlanmaktadır. Ayrıca, 1-3. dizelerde "her", 4-5. dizelerde "ol" kelimelerinin öncelenmesinin aynı zamanda, dize başlarında bir ses uyumu oluşturmak amacıyla yapılmış bir aliterasyon ${ }^{3}$ olduğu da unutulmamalıdir.

Yine aynı 1. dizelerin sonlarında da şu birbirine benzer söz kuruluşları (1-3, 4-5, 6-7) yer almıştır (sonlama):

1. by. - -dan nişân virür

2. by. -dan sudûr ider

3. by. -da derc olur

4. by. ... nutk-umun

5. by. ... şi'r-ümün

6. by. ... her söz-üm

7. by. ... kasâid-üm

Yukarıda gösterilen 7 beyitte yapılmış sonlamaların da, nazımdaki görevi ve işlevi açısından öncelemelerden hiç bir farkı yoktur. Ancak bu sonlamaların, söz konusu beyitlerin dize başlarındaki eş görevli öncelemelerle bir arada kullanıldığında hiç kuşkusuz daha güçlü ve etkili bir sonuç ortaya çıkmaktadır. Bu nedenle, bu 7 beyitteki önceleme ve sonlamaların, her hangi bir anlatım zorunlululuğundan değil, şairin yaratıcı üstün sanat gücünün bir ürünü olarak düzenlenmiş olduğu açık seçik bir biçimde anlaşılmaktadır.

Şair 1. dizelerdeki bu önceleme ve sonlamalarla da yetinmeyerek, "fahriye" konusunu daha da abartmak için 2., 3., 4. ve 5. beyitlerin 2. dizelerinin başına da, yine kendi şiiri ve sanatına gönderme yapan tamlanan kuruluşundaki kelimeleri önceleyerek yerleştirmiştir. Burada hemen belirtilmelidir ki öncelenen kelimeler, eğer, belirtili ad tamlamalar kuruluşuyla dize içerisinde yan yana yer almış olsaydı, bu türlü kulla-

3 Kimi devriklemelerin, eski Türk şiirinden beri "başlangıçtaki sesin tekrarlanması amacıyla yani aliterasyon için yapıldığı" bilinmektedir. Bu konu için bkz. Mihail Simyonoviç Fomkin, "Sultan Veled (1226-1312)'in Şiir Sanatı ve Türk Şiir Geleneği", Türk Dili Araştırmaları Yıllı̆̆ı-Belleten 1991, TDK Yay., Ankara 1994, s. 141. 
nımların yarattığı etkiden eser kalmazdı. 4. ve 5 . beyitlerdeki "nutkumun feyzi" ve "şi' rümün reşki" tamlamalarının ikiye bölünerek dize sonlarında ve dize başlarında yer alacak biçimde düzenlenmesi, beyitlerin okunuşunda tamlanan kelimeler üzerinde bulunan "cümle vurgusu"na aynı zamanda bir de "abartma vurgusu"4 görevi ekleyerek o kavramların daha da ön plana çekilmesini sağlamıştır. 2. dizelerin başında yer alan söz konusu tamlanan öncelemeleri şöyledir:

2. by. (nazmumun) Lafzi...

3. by. (kelâmumun) Mazmûnı...

4. by. (nutkumun) Feyzi...

5. by. (şi' rümün) Reşki...

Bunlara ek olarak, 9. beytin 1. ve 2., 10. beytin de 2. dizesinde "tab"um, endîşe-m, hâme-m" kelimeleri yine aynı amaçlarla öncelenmiştir. 9. beytin 2. dizesinde "endîşe-m" kavramından sonra "kalem-üm" kavramı da getirilmiştir. Bu kavramların 1. kişi iyelik ekleriyle vurgulanarak kullanılması önceki beyitlerde sıkça geçen -um/-üm kullanımını yaygınlaştırarak Kaside'nin kompozisyonu açısından "fahriye" beyitlerindeki 1. kişi anlatımını güçlendirmekte, "ben" kavramına verilen önemi daha da pekiştirmektedir:

9 Tab'um arûs-ı ma'niye meşşâtalık ider

Endîşem âyine kalemüm sürme-dân virür

10 Hâmem ki nazmumı ider ihyâ midâd ile

Âb-1 hayâta reşhası rûh-1 revân virür

Kısaca değinilen, beyitlerdeki bu söz düzeni ve söyleyiş kalıpları Kaside'ye, güzel bir "geometrik yapı" görünümü kazandırmıştır.

Nef'î yukarıdaki "fahriye" beyitlerinde, övünme kavramı açısından ben zamirini ve 1 . kişi -um/-üm iyelik ekini sıklıkla kullanmakla, Kaside'nin daha sonra gelen "medhiye" bölümünde Sultan I. Ahmet'i anlatan "ol" 3. kişi zamirine "övme" kavramı açısından gönderme yaparak

${ }^{4}$ Bkz.Tahsin Banguoğlu, Türkçenin Grameri, TDK Yay., 3. bas., Ankara 1990, s. 122. (Bu terim, Prof. Banguoğlu'nun kitabında "obartma vurgusu" biçiminde geçmektedir.) 
ben/o, öven/övülen arasındaki bağı güçlendirmiştir. Ayrıca, bu türlü bir ben'li anlatımla Nef'î, "güçlü şairlik yeteneğini" her yönüyle tanımladıktan sonra aşağıda verilen 11. beyti söyleyebilmek için uygun bir ortam hazırlamıştır. Söz konusu beytin başındaki "bu” gösterme sıfatı da, Kaside'nin başından beri Nef' î’nin anlattığ 1 kendi "tab'1"nın üstünlüğünü, büyüklüğünü, düzeyini, erişilmezliğini, yaratıcıllğını... açık seçik olarak belirtmek amacıyla öncelenmiştir. Bunun yanı sıra "bu" sözünde yapılan imale de bir kusur değil, bu anlamları vurgulamak, pekiştirmek için özellikle yapılmış bir ses sanatıdır. Ayrıca "bu" gösterme sıfatındaki imale, beyitteki karşıt düşünceyi de güçlendirmektedir:

11 Bu iktidâr-1 tab' ile ammâ ne fâide

Ser-mâye-i tasavvuruma gam ziyân virür

Nef'î yine bu Kaside'sinin medhiye bölümünde başka söz kalıpları yanında, yukarıda Fuzulî'nin Kaside'sinde olduğu gibi arka arkaya gelen 3 beytin her dizesinde Sultan I. Ahmet'e ilişkin olarak (onun...) "devri, şemşîri, kahrı, hulkı, şânı, lutfı" tamlananlarını önceleyerek bu kavramlar açısından padişahın özelliklerini, niteliklerini ve etkinliklerini ön plana çıkarıp görkemli bir anlatım içerisinde vermeyi başarmıştır. Böyle bir anlatımla Nef'î, I. Ahmet'in övgüsüne temel olan kavramlara yalnızca dikkati çekmekle kalmamış, aynı zamanda dizelerin başına çekilen "cümle vurgusu"nun üzerine "abartma vurgusu"nu da bindirerek padişahın özelliklerinin en üst düzeyde dile getirilmesini sağlamıştır:

Devri zamân-1 Ahmed-i Muhtâr'ı andurur

Şemşîri Zü'l-fekar-1 Alî́den nişân virür

Kahrı sipihr-i pür-sitemün od ider yirin

Hulkı cihâna bûy-1 gül ü gül-sitân virür

Şânı şehân-1 âlemi hâr u hakîr ider

Lutfı gedâya saltanat-ı câvidân virür

Nef'î́nin bir kasidesinden aktarılan yukarıdaki birkaç örnek beyit bile, onun duygu ve düşüncelerini anlatmak, renkli imgeler yaratmak, el değmemiş mazmunlar oluşturmak, kendine özgü bir şiir dili kurgulamak için kelime seçimi konusunda ne denli bir sanatkâr olduğunu açıkça göstermektedir. Ele aldığı konu açısından soyut kavramları an- 
latmak için seçtiği kelimeler, onun şiir dilinde sanki elle tutulur gözle görülür somut bir varlığı betimliyormuş, tanımlıyormuş gibi bir işlevle karşımıza çıkar. Zaten Nef'î́nin şiir dili kelime hazinesi yönünden çok zengindir. $\mathrm{O}$, "kelimeleri konuya göre seçmede ve beyan ahenginde büyük başarı göstermiştir ${ }^{5}$."

Yine Fuzulî́nin yukarıdaki Kaside'sinde yaptı̆̆ı gibi Nef'î de bu Kaside'sinde, hemen bu 3 beyitten sonra yine Sultan I. Ahmet'in "bir vezîr" $\mathrm{i}$ ve "bir vekîl"inin görevlerini anlatırken, aşağıdaki beytin dizeleri başında "geh" belirtecini önceleyerek padişahın "Acem şahı" ve Tatar askeri" üzerindeki egemenliğinin sürekliliğini ve yeryüzünde her ülkeye ulaşan yaygınlığını vurgulamaya çalışmıştır:

Geh bir vezîri şâh-1 Acem'den harâc alur

Geh bir vekîli asker-i Tâtâr'a han virür

Nef'î́nin bu Kaside'sinde çok az bir bölümünü sergilediğim birer anlamsal birim niteliğindeki söz kalıplarının dışında, sözdizimsel yapı oluşturan başka söz ve anlatım kalıpları da bulunmaktadır; ancak bunlara konu dışı olduğu için değinilmemiştir. Yukarıda Fuzulî́nin ve Nef'î́nin kasidelerinden verilen anlatım kalıbı örneklerinin bir bölümü zaten, divan şiirinin stilistik özellikleri açısından her şairde görülen ve uygulanan söz yapılarıdır, Fuzulî̀ye ve Nef'î́ye özgü değildir; ancak şairler bunları kendi edebî kişiliklerine uyan ve üslûp inceliklerine yak1şan biçimlerde kendileri için özgüleştirerek kullanmışlardır. Bu konuda son olarak şunu da belirtmekte yarar görüyorum, Fuzulî́nin ve Nef'î́nin kasidelerinden gösterilen bu söz kalıpları ve düzenleri, dilbilgisel açıdan cümle çözümlemelerine taban oluşturacak veriler olarak algılanmamalı; bunlar, şiir çözümlemelerinde (ve şerhlerinde) birer stilistik öğe olarak değerlendirilmelidir.

Şiir dilindeki her çeşit öncelemenin, beytin içeriğiyle yani beyitte "ne söylendiği"yle doğrudan ve yakından bir ilgisi vardır. Bunun sonucunda ortaya çıkan beytin söz yapısında "içerik"in "nasıl söylendiği" konusu da büyük bir önem kazanır. Beyitte "ne söylendiği" insanı hayrette bırakabilecek ne kadar yüce bir düşünce de olsa, bunun şiirsel bir

\footnotetext{
${ }^{5}$ Fatma Tulga Ocak, “Nef'î ve Eski Türk Edebiyatımızdaki Yeri”, Ölümünün Yüzellinci Yılında Nef'î, Atatürk Kültür Merkezi Yay., Ankara 1987, s. 1-44.
} 
etki yaratabilmesi ancak "nasıl söylendiğii" ile sağlanabilir. Şiirde amaç öncelikle bilgilendirmek değil, bunun yanı sıra duygulandırmaktır. Bunun için beytin, gelişi güzel değil belli bir söz düzeni ve yapısı içerisinde söylenmesi gerekir.

Ĕ̆er "teşbihte hata olmazsa", beyitte "ne söylendiği" konusu ile beytin "nasıl söylendiği" konusu şöyle bir metaforla anlatılabilir: Çatısı çökmüş, duvarları yıkılmış, kapısı penceresi dağılmış bir evin eşyaları ne denli güzel ve değerli olursa olsun göçüyormuş gibi darmadağınık olarak ortalıkta duruyorsa; yerli yerine konmuş, zevkle döşenmiş sağlam bir evin yaptığı etkiyi yapması asla beklenemez. Düzenli bir evde eşyalar sıradan da olsa insanın içini rahatlatan bir etki yapabileceği açık bir gerçektir. İşte bu nedenle şairlerin "ne söylediği" ile "nasıl söylediği" kavramları arasındaki ilişki, dağınık bir ev ile düzenli bir ev arasındaki ilişki gibidir. Kısaca, eşyaların antika değerinde (öz, içerik) olması yetmez, bunların değerleri oranında düzenlenip yerleştirilmesi (biçim, deyiş) de gerekir. Bu düşünceler doğrultusunda divan şiirinde söz ve anlam açısından sağlam, düzenli ve dengeli bir bütünlük gösteren "beyt"in bir anlamının da " $\mathrm{ev}^{7 "}$ olduğu unutulmamalıdır.

Kasidelerde ya da anlam bütünlüğü olan gazellerde (yek-âhenk) şiirin kompozisyonu doğrultusunda sergilenen konunun bir yönüne odaklanmayı sağlama ya da o yönünü vurgulama amacıyla bir anlatım özelliği olarak türlü öncelemelere baş vurulur. Bunlara benzer amaçlarla pek çok kasidede koşut beyitler de yer yer kullanılmıştır. Koşutluk, belli

\footnotetext{
6 "Ne ...diği" ve "nasıl ...diği" anlatım kalıbı, pek çok olaya ve duruma uygulanabilecek bir özellik ve geçerlilik taşıyan büyülü bir göstergedir. Bu söz kalıbı, giyimdeki zevk ve zarafeti nitelemek için "ne giydiği" /"nasıl giydiği" biçiminde kullanılmıştır. Milliyet Gazetesi'nin 5 Kasım 2007 tarihli sayısının 28. sayfasında çıkan bir haber bu anlatım kalıbını yansıtması nedeniyle çok ilgimi çekmişti. Kısaca haberin konusu, İngiltere'de yayımlanan ünlü moda dergisi Vogue'un, "Zarafetiniz ne giydiğinizle değil, nasıl giydiğinizle ilgilidir." diyerek 81 yaşındaki Kraliçe II. Elizabeth'i dünyanın en zarif kadını ilan etmesiyle ilgilidir.

7 "İki dizeden oluşan nazım" anlamındaki "beyt"in "ev"le ilişkilendirilişi semantik açıdan Kamus'ta şöyle anlatılmıştır: “(el-beyt) ... iki mısrâdan mürekkeb manzûmeye itlak olunur gûyâ ki sakf ve imâd ve sâir edevâtdan cem‘ ve binâ kılınmış beyte teşbîh olunmuşdur", Ahmed Âsım, Okyânûsü'l-Basît fî-Tercemeti'l-Kamûsi'lMuhît, İstanbul 1268 (1851), c. 1, s. 295.
} 
amaçlara yönelik olarak önceleme ve yinelemeyle oluşturulduğu durumlarda başka anlatım özelliklerine oranla sözün etkileyici gücünü artırmak açısından daha geniş kapsamlıdır. Bu türlü amaçlarla koşut bir yapı içerisinde söylenmiş beyitlerin pek çok yetkin örneği Fuzulî́nin ve Ahmed Paşa'nın ${ }^{8}$ kasidelerinde görülebilir. Her hangi bir olaya, duruma, olguya, işleve, kişiye, nesneye, kavrama... belirleyici bir nitelik katmak, bunlarda var olan bir özelliğe dikkati çekmek ya da önemsenen her hangi bir şeye gönderme yapmak amacıyla pek çok mesnevinin beyitleri arasında da aynı önceleme ve koşutlama örneklerine rastlanmaktadır.

Şiir çözümlemeleri ve stilistik incelemelerde öncelemeler, şu alanlarda ele alınmaktadır: Görsel öncelemeler, sesbilgisel öncelemeler, biçimbilgisel öncelemeler, sözdizimsel öncelemeler ve anlam öncelemeleri (Özünlü 1997: 75-99).

Bu yazıda önceleme konusuna, genellikle sözdizimsel ve anlam öncelemeleri alanlarına giren kullanımlar, kuruluşlar ve düzenlemeler açısından çok sınırlı bir ölçüde yaklaşılmıştır. Özellikle Fuzulî'den seçilenleri desteklemek amacıyla başka şairlerden verilen örneklerin değerlendirilmesi, konunun geniş ve kapsamlı olması nedeniyle ana çizgileriyle ele alınmıştır.

Sözdizimsel öncelemeler açısından divan şiirine bakıldığında cümlenin her öğesinin anlam ve duygu değerine göre öncelenebildiği ve bu yolla cümlenin devrikleştirilebildiği bilinen bir gerçektir. Ancak, üzülerek belirtmek gerekir ki, divan şiirindeki bu türlü söz düzenlemelerinin şiir dili ve şiirsel anlam açısından taşıdıkları "yazınsal değerler" üzerinde gerektiği ölçüde önem verilerek durulmadığı görülmektedir.

Nedim'in Damat İbrahim Paşa'ya sunduğu İstanbul "vasfı"ndaki ünlü kasidesinin ilk beyti (Gölpınarlı 1972: 85), pek çok kişinin gönlünde ve dilinde yer etmiş örneklerdendir:

Bu şehr-i Stanbul ki bî-misl ü bahâdur

Bir sengine yek-pâre Acem mülki fedâdur

\footnotetext{
${ }^{8}$ Koşutluk ve koşut beyitlerin özellikleri ile kasidelerde hangi amaçlarla kullanıldığı konusu için bkz. Cem Dilçin, "Ahmed Paşa'nın Şiirlerinde Paralelizm", İstanbul'un Fethinin 550. Yılı Anı Kitabı, DTCF Yay., Ankara 2004, s. 55-72.
} 
Nedim'in ölüm tarihi olan 1730'dan günümüze kadar geçen 278 yıldır bu beytin dillerden düşmemesinin sırrı acaba nedir, nerededir? Hiç kuşku yok ki bunun en baş nedeni "Bu şehr-i Stanbul" sözünün anlamı pekiştirici başka bir takım öğelerle desteklenerek öncelenmiş olmasıdır. "Bu" gösterme sıfatı, İstanbul şehrini her hangi bir şehir olmaktan çıkarıp, onu belirli, bilinen, yaşanılan, sevilen, benimsenen ve bütün coğrafî, tarihsel, kültürel özellikleri ve değerleriyle bir dünya şehri, bir "pây-1 taht" olduğunu vurgulayan en çarpıcı öğedir. Ayrıca, "bu" sıfatında vezin gereği yapılan imaleye, bir ses sanatı olarak İstanbul'un söz konusu özelliklerini abartıcı bir görev de yüklenmiştir. İstanbul kelimesinin "-bul" hecesindeki med de, kentin bütün değerlerinin ve güzelliklerinin boyutlarını insan aklının sınırlarını aşan uzaklıklara taşıyan ikinci bir ses sanatıdır. Bir aruz kuralı olan bu imale ve med, arka arkaya gelerek beyitteki konumları açısından anlamı abartmanın boyutlarını daha da genişletmektedir. Semantik açıdan kısaca belirtmeye çalıştığım "Bu şehr-i Stanbul" sözü, yukarıdaki anlam ve yorumların yaptığı çağrışımlarla daha da derinlik ve yoğunluk kazanarak günümüzde uzunca bir süredir benzeri ortamları tanımlamak, betimlemek, oralara bir özellik verebilmek, farklılık katabilmek için kullanılır olmuştur. Bu kullanım yaygınlaşınca, Nedim'in bir kasidesinin ilk beytinin ilk parçası olan bu söz onun olmaktan çıkmıs, bir anlamda deyimleşerek dil içerisinde her duruma uyarlanabilen bir söz kalıbı niteliğine bürünmüştür.

Her öncelemenin başarılı olup olamayacağı açısından Nedim'in bu beytiyle Ziya Paşa'nın "Çerâğan Sâhil-serây-1 Hümâyûn"u "vasfı"nda Sultan Abdülaziz için söylediği bir kasidenin nesip bölümünde İstanbul'un övgüsündeki aşağıdaki beyit karşılaştırılınca (Göçgün 1987: 146) çok farklı bir sonuç ortaya çıkmaktadır:

Stanbul şehri reşk-endâz-ı heft-iklîm-i devrândır

İki bahre iki iklîme zîrâ pertev-efşândır

Ziya Paşa bu Kaside'sini yazarken hiç kuşkusuz Nedim'in Kaside'sinden etkilenmiş ve esinlenmiştir. Hatta bu Kaside'nin, farklı vezin ve kafiyede ancak aynı redifle Nedim'e söylenmiş bir nazire olduğunu belirtmek de yanlış olmaz. Ziya Paşa'nın Kaside'sinde yaptığı önceleme konusunda kısaca söylemek gerekirse, beytin başındaki "Stanbul şehri" sözü, bir kenti bildirmek için kullanılan sıradan bir ad tamlamasından 
ileriye gitmemekte, Nedim'in kullanımında bulunan hiç bir sanatsal özelliği taşımamaktadır.

Yine Nef'î́nin Sultan I. Ahmet'e sunduğu ve Edirne şehrinin "ta'rîf"inin yapıldığı kasidenin matlaı da şöyle başlamaktadır (Dîvân 1252: Kas. s. 13):

Edrine şehri mi bu yâ gül-şen-i me'vâ mıdur

Anda kasr-ı pâdişâhî cennet-i a'lâ mıdur

Nef'î́nin bu beytindeki önceleme, Nedim'in söyleyişindeki güzelliğin kimi özelliklerini yansıtmaktadır. Divan şairleri bilindiği gibi, kendilerinden önceki bir şairin kullandığı bir mazmunu, bir söylemi daha güzel bir biçimde yeniden düzenlemeyi hep denemişlerdir. Bana göre Nedim, Nef'î́nin bu öncelemesini değerlendirip onun söylemine önemli birkaç semantik öğe katarak daha etkili bir biçimde söylemeyi başarmıştır. Ancak bu değerlendirmeden Nef'î́nin öncelemesinin başarısız olduğu sonucu çıkarılmamalıdır. "Edrine şehri mi bu" sözünün bir soru cümlesi içerisinde "tecâhül-i ârifâne"yle dile getirilmesi, Edirne şehrine ilişkin bilinenlerin gerçekliğini abartarak anlatmak açısından çok etkili bir anlatım yolu olmuştur. Nef'î́nin beytinde de her ne kadar öncelenmemiş de olsa, "bu" sıfatının imaleli olması, kentin taşıdığı değerlere gönderme yapmak ve onları vurgulayıp abartmak açısından çok etkilidir.

Yukarıda Nedim'in ve Nef'î́nin beyitlerinde geçen ve anlamı pekiştirip abartmak amacıyla yapılmış çok başarılı ses sanatı örneği olabilecek nitelikteki imaleler dışında, öncelemenin anlama kazandırdığı ve iletişime kattığı değerleri yitirmeme amacıyla kullanılmış, ancak kusur olarak algilanabilecek kimi imaleler de yapılmıştır. Durum böyle de olsa, veznin büyük şairleri zorlamadığı, buna karşılık büyük şairlerin vezni zorladığı unutulmamalıdır. Ahmed Paşa'nın aşağıdaki matlaında (Tarlan 1966: 305) olduğu gibi şairler, dizeleri ağır imalelerden arındırarak vezne daha yatkın bir sözdizimi içerisinde söyleyebilecekken anlamın odaklandığı iki tümleci önceleme yolunu seçerek anlamı öne çıkarmışlar, deyim yerindeyse anlamı feda etmeyerek vezni anlamin hizmetine sokmuşlardır.

Yüz mi döyer yüzüne bâğ-1 cinândur dimeğe

Dil mi varur lebüne çeşme-i cândur dimeğe 
Bu beyitte, vezin yönünden "döyer" ve "varur" kelimelerinin ilk hecelerinde ağır bir imale yapılmasına karşın Ahmed Paşa'nın, kendi şiir sanatına özgü cümle (dize) düzenleme (phraseology) çabası apaçı görünmektedir. Çünkü beyti, feilâtün feilâtün feilâtün feilün veznine uygun olarak "döyer" ve "varur" kelimelerinde imale yapmadan aşağıda olduğu gibi iki ayrı düzenlemeyle (tedvîr ${ }^{9}$ ) söyleme olanağı varken Ahmed Paşa "mi" soru ekini önceleyerek "yüz" ve "dil" kavramlarını öne ç1karmıştır. Buna bağlı olarak "yüz/bâğ-1 cinân, leb/çeşme-i cân" sözleri arasında kurulmuş yatay leff ü neşr sanatını ve yüz-dil (başkalarının)/ yüzleb (sevgilinin) sözleri arasındaki karşıtlığ da pekiştirmiştir:

- Yüz döyer mi yüzüne bâğ-1 cinândur dimeğe Dil varur mı lebüne çeşme-i cândur dimeğe

- Yüzüne yüz mi döyer bâğ-1 cinândur dimeğe Lebüne dil mi varur çeşme-i cândur dimeğe

Ahmed Paşa'nın beytini tedvîr ederek benim düzenlediğim yukarıdaki iki biçimde, "döyer" ve "varur" eylemlerindeki imaleler kalkmış olmasına karşın, beytin aslındaki söz diziminin dağılması nedeniyle "yüz mi", "dil mi" öncelemeleriyle anlatılmak istenilen "olumsuzluk" vurgusu yok olmuştur.

$\mathrm{Bu}$ yazıda öncelikle ele alınan yüklem öncelemelerinin dışında, türlü ulaçların öncelendiği şiirler yani bir ulaç öncelemesiyle başlayan şiirler bu açıdan değerlendirildiğinde, şiiri derinleştirecek pek çok anlam inceliklerinin ortaya çıktığ1 görülecektir. İlm-i Belâgat'ta eskilerin "hüsn-i ibtidâ" terimiyle anlattıkları durum, yani "söze başlamadaki güzellik" biraz dar bir anlamla, yukarıda verilen önceleme alanlarının birkaçında geçerli olan uygulamalarla örtüştürülebilecek bir özellik göstermektedir. Pek çok örnekten aşağıda iki büyük şairden verilen iki ünlü şiir birer ulaçla başlamaktadır. Bu iki şiirin etkileme gücünün, belli bir oranda da olsa, bu ulaçların şiirin konusu açısından çağrışım değerleri düşünülerek öncelenmesi (hüsn-i ibtidâ) gerçeğine dayandığında hiç bir kuşku yoktur.

\footnotetext{
${ }^{9}$ Akis (aks) sanatının bir türü olan tedvîri Tahir Olgun Edebiyat Lügati adlı eserinde şöyle tanımlamaktadır: "Bir mısrâdaki kelimelerin yerini değiştirmekle veznin ve mânânın bozulmaması, yâni, yine aynı meâlin anlaşılmasıdır." (İstanbul 1937, s. 135).
} 
Yazının çerçevesini aşmamak için bunların daha geniş bir çözümlemesine girmeden söz konusu iki güzel örneği anımsatmakla yetiniyorum. Namık Kemal'in Vatan Kasidesi adıyla da anılan Hürriyet Kasidesi, ikinci dizenin başına getirilerek kesin yargılı "çekildik" yüklemiyle pekiştirilen "görüp" ulacının 1. dizede öncelenmesiyle başlamaktadır ${ }^{10}$ (Akyüz 1970: 61). Şair bu ulaçla şiire başlayarak, "görmek" kavramına ilişkin olmak üzere, metnin arka planında "ahkâm-1 asr" doğrultusundaki olumsuzlukları yansıtan düşünce ve simgelere göndermeler yapmıştır. Bu ulaç bir anlamda, dikkati görüp/çekildik eylemlerinin vurguladığ1 yargıya çekerek ilerideki beyitlerde söz konusu edilen olumsuzlukları gerektiği biçimde algılayabilmesi açısından okuyucuyu koşullandırma göreviyle kullanılmıştır:

Görüp ahkâm-ı asrı münharif sıdk u selâmetten Çekildik izzet ü ikbâl ile bâb-1 hükûmetten

Bana göre yukarıda çok kısa olarak değinmeye çalıştığım önemli bir stilistik işlevle öncelenmiş olan "görüp" ulacının Namık Kemal'in şiirinin ilk kelimesi olarak kullanılmasını değerli hocamız Mehmed Kaplan çok sert olarak şöyle eleştirmektedir: "Nazım ile "konuşma"sını bilen bir

${ }^{10}$ Mehmed Kaplan, Namık Kemal'in Hürriyet Kasidesi'ni Leskofçalı Galip'in Divan'ındaki aşağıdaki beyitten duygulanarak yazdığını bir mektubuna dayanarak belirtir (Kaplan 1963: 28):

Olup mecrûh-i peykân-1 havâdis tâir-i devlet

Dem-â-dem hûn akar çeşmim gibi enzâr-1 milletten

Görüldüğ̈̈ gibi bu beyit de yine bir ulaçla, "olup" ulacıyla başlamaktadır. Namık Kemal'in bu beytin "mazmûn"undan duygulandığı çok açık olmakla birlikte, söyleyiş biçiminden esinlendiği, söz diziminden, söz kalıbından etkilendiği de açıkça belli olmaktadır. Leskofçalı Galip'in beytindeki söylem içerisinde "olup" ulacının semantik açıdan taşıdığı güçlü ve vurucu etkiyi sezen Namık Kemal de 31 beyitlik Kaside'sine, bu şiiriyle yaratmayı amaçladığı etkiye uygun olabileceğini düşündüğü "görüp" ulacını önceleyerek başlamış olmalıdır. Bu durumu bir öykünme (taklit) olarak düşünmemek gerekir. Bana göre, ülkesine ve ulusuna karşı çok güçlü bir tutkuyla bağlı olan bir şairin, bu yöndeki kendi duygularını dile getirebilmek açısından o "söz kalıbı"nı uygun bir kalıp olarak görmesinden daha doğal bir şey olamaz. Divan şiirinde "nazire", bir yönüyle aynı vezin, kafiye, redif ve "söylem"le ya da benzer "söz kalıpları" yla değişik duygu, düşünce ve imgeleri dile getirmek için yazıldığı gibi, daha önce söylenmiş bir "mazmûn" u ondan daha güzel bir biçimde söylenebileceğini göstermek amacıyla da yazılabilmektedir. 
şair, eserine "görüp" diye başlamaz. Nesrinde gerundifi sevmeyen Kemal'in onu nazma sokması bir zâ'f eseridir." (Kaplan 1963: 33)

Oysa Namık Kemal, gazellerinin ilk kelimesi yerinde başka ulaçların yanı sıra -ıp/-ip ulacını 3 gazelinin matla beytinin yine ilk kelimesi olarak önceleyerek kullanmıştır. Divan şairlerinin pek çoğunda da görülen bu kullanımın yadırganacak bir uygulama olmadığı, tam tersine etkin bir üslûp öğesi olarak kullanıldığı ve şairler tarafından bilinçli ve bilerek öncelendiği kanısındayım. Gazellerinde öncelediği başka ulaçların yanında, yalnızca -ıp/-ip ulacının kullanımına ilişkin aşağıdaki beyitler bile, yukarıdaki eleştirinin tersine Namık Kemal'in bu konuda geleneği nasıl izlediğini gösteren örneklerdendir. Aşağıdaki matlalardan birincisi 16 beyitlik "na' $t$ " konulu bir gazeldendir:

- Edip fülk-i cihân-peymâ-yı dil azm-i yem-i ma'nâ Açlldı bâd-bân-ı aşk b'ism'llâhi mecrâhâa ${ }^{11}$ (Ergun 1941: 68)

- Gösterip mahşere bir dâğını her çâk-i tenim Olur âbisten-i sad mihr-i kıyâmet kefenim (Ergun 1941: 133)

- Verip âfâka lerziş na' re-i mestâne-i aşkın Felek zannetme oldu ser-nigûn peymâne-i aşkın (Ergun 1941: 154)

Fuzulî, -ıp/-ip ekiyle çekimlenmiş ulaçları birkaç gazelinde öncelediği gibi, iki gazelinin matlaının her iki dizesinde de anlamı pekiştirmek amacıyla başa çekmiştir:

- Girüp mey-hâneye muğ meşrebiyle kim ki hû eyler Olup mü'min behişte kâfirem ger ârzû eyler (s. 205)

- Görüp mühlik menüm çevremde bahr-i 1şk tuğyânın Kaçup bir dağa çıhmış Kûh-ken kurtarmağa cânın (s. 348)

Bakî'nin hocası Karamanlı Mehmet Efendi'ye sunduğu Sünbül Kasidesi "urınup" ulacının öncelendiği bir beyitle (Küçük 1994: 62) başlamaktadır:

${ }^{11}$ Ergun, bu gazelin Leskofçalı Galip'in aşağıda matlaı verilen gazele nazire olduğunu göstermiştir (Ergun 1941: 69):

Olup mersâ-yı hikmetten ser-efrâz-1 yem-i ma'nâ Açıldı keşti-i endîşe b'ism'llâhi mecrâhâ 
Urınup farkına bir tâc-1 mücevher sünbül

Oldı iklîm-i çemen tahtına server sünbül

Nedim de Sadrazam Şehit Ali Paşa için olan kasidesinin ilk beytinin (Gölpınarlı 1972: 3) başında "başlayup" ulacını öncelemiştir. Nedim, bu Kaside'sinin nesibinin bir bölümünde "fahriye" beyitlerine yer vermiş, şiiri ve sanatıyla övünmüştür. İşte bu "başlayup" ulacının konumu, $\mathrm{Ne}$ dim'in şiir söylemeye "başlaması"yla sanatının nasıl bir coşkunluğa ulaştığını yansıtması açısından önemlidir:

Başlayup cûşişe tab'umda mezâyâ-yı sühan

Mevc-hîz oldı yine lücce-i deryâ-yı Aden

Yahya Kemal'in Süleymâniye'de Bayram Sabahı adlı şiiri de başlangıcı etkili bir ulaç olan örneklerdendir (Beyatlı 1963: 9). Şiir, türlü motiflere dayandırılarak geçmişten günümüze ulaşan, gözleri ve gönülleri dolduran tarihî, dinî, millî... olaylara, "1şık" ve seslere çağrışım yoluyla göndermeler yapma görevi yüklenmiş "artarak" ulacıyla başlamaktadır:

Artarak gönlümün aydınlığı her sâniyede,

Bir mehâbetli sabâh oldu Süleymâniye'de.

Şiirin sonunda şair, yüzyıllardır gittikçe "artarak" bir "bayram sabahı"na ulaşan tarihî, dinî, millî, manevî, toplumsal, kültürel bir bütünlükle iç içe geçmiş olayların, kişilerin, nesnelerin simgesi niteliğindeki "1şıklar"1n "gönlü"nü nasıl "doldurduğu"nu da "tek dizelik bir "bent"le şöyle özetliyor (Beyatlı 1963: 13):

Doludur gönlüm ışıklarla bu bayram sabahı.

Bu türlü sözdizimsel yapılar içerisinde kurulan cümlelerde devrikleme ya da önceleme sonucunda ilk sirada yer alan söz, hangi kelime türünden ve cümlenin hangi öğesi olursa olsun okuyucuyu etkileme, yönlendirme, yargıyı pekiştirme ya da kanıtlama, belli çağrışımlar uyandırma, bellekte kalıcılık sağlama... gibi görev ve işlevlerle donatılmıştır. Şairler bunların birini ya da birkaçını bu amaçlarla bilinçli olarak kullanırlar.

Sözdizimsel öncelemeler arasında "yine" belirtecinin çok yaygın bir kullanım alanı vardır. Bu türlü örneklerin incelenmesinden de ilginç açılımlara ulaşılabilmektedir. Kısaca değinmek gerekirse, "yine" belirtecinin (yüklemden önce ve sonra gelerek) en önemli ve güçlü işlevi "sü- 
reklilik" özelliğini vurgulamak, zaman dilimleri içerisinde belli olaylar açısından geçmiş/gelecek, olmuş/olacak... gibi bir süreç ilişkisi, hatta kimi zaman da duygusal bir bağ kurmaktır. Buna bağlı olarak bir görevi de, içine girilen yeni dönemin, yaşanılan yeni durumun daha önceden de bilindiği ve daha eskiden de yaşanmış olduğu "yine" belirteciyle ortaya konularak, okuyucuya, bugünden geçmişe hatta geleceğe bile uzanan bir geniş zaman dilimini kapsayacak bir açlım sağlamaktır. "Yine" belirtecinin aynı zamanda yok olmuş, elden çıkmış bir kişinin, nesnenin, durumun, olgunun yeniden ortaya çıkması ya da ona kavuşma duygusuyla insanı etkileyecek güçlü bir coşku yaratma işlevi de vardır.

Örneğin "yine"12 belirtecinin öncelendiği, Bakî'nin ve Nef'î́nin şiirlerinden seçilmiş beyitlerdeki öncelemeler, bir rastlantı ya da vezin, kafiye zorlamasına bağlanamayacak güzel örneklerdir ${ }^{13}$. Bu beyitlerde, kimi öncelenmemiş "yine" belirteçlerine yinelenmeleri (tekrîr) nedeniyle öncelenenlerin anlamlarını pekiştirme ve güçlendirme işlevi de yüklenmiştir. Bu örneklerdeki (yine) + (tekil 3. kişi -di'li geçmiş çekimli yüklem) ya da bunun tersi durumundaki (yine) $+(-d \imath),(-d \imath)+($ yine) kullanımlarına dikkat edilmelidir. Daha az olmak üzere (yine $)+(-m ı s ̧),(-m \imath s ̧)+($ yine $)$ biçiminde kullanımlara da rastlanmaktadır. (Aşağıdaki beyitlerde öncelenen "yine" belirteci siyah harflerle, "yine" belirteciyle birlikte kullanı-

12 "Yine" belirtecinin Türkçe Sözlük'teki "1. Yeniden, bir daha, yine, tekrar, gene. 2. Öyle de olsa, öyle olmasına karşılık. 3. Buna rağmen, bununla birlikte." (TDK Yay., 10. bas., Ankara 2005, s. 2184) anlamlarının yanında, Ahmet Vefik Paşa'nın Lehce-i Osmânî́sinde geçen "... mükerreren, ez-ser-i nev, tekid için hatta, bir daha manasina, yine bir kere daha." anlamları da (Haz. Prof. Dr. Recep Toparlı, TDK Yay., Ankara 2000, s. 427) dikkate alınmalıdır.

${ }^{13}$ Yinelenen bir özelliğin ya da öğenin stilistik açıdan taşıdığı işlevlerini incelerken, değerlendirir ve yorumlarken bunların şairin dilinde belli bir kullanım sıklığına ulaşmış olmasına, izlenebilir bir süreklilik ve görülebilir bir yoğunluk kazanıp kazanmamış olmasına bakmak gerekir. Bazı çalışmalarda görüldüğü gibi bir rastlantı sonucu kullanılmış bir iki öğeyi ele alarak "üslûp özelliği" gibi değerlendirmek konuyla ilgilenenleri yanıltıcı bir sonuca götürmektedir. Bu nedenle üzerinde durulan önceleme öğelerinin bir rastlantı sonucu ortaya çıkmadığını gösterebilmek için bu yazıda biraz bolca örnek verme yoluna gidilmiştir. Ancak bu örnekleme de, yazıyı okuyanlar üzerinde gereksiz yere uzatılmış etkisi yaratmamak için olabildiğince çok sınırlı tutulmuştur. Yoksa bu konunun uzmanlarınca açık seçik olarak bilindiği gibi divan şiiri ve genel olarak Türk şiiri söz konusu örnekler açısından çok zengin ve tükenmez bir kaynaktır. 
lan -di'li geçmiş zaman çekimindeki yüklemler ve öncelenmemiş "yine" belirteçleri italik harflerle gösterilmiştir.)

Bakî̀nin Sultan III. Mehmet'e sunduğu Kudûmiye'nin ilk beyitleri (Küçük 1994: 33) şöyledir:

Bi-hamdi'llâh refîk oldı yine tevfîk-i Rabbânî

Muzaffer kıldı sultân-ı cevân-baht-ı cihân-bânı

Kudûm-1 şâh ile halkun bu gün başına gün toğd1

Yine tâb-ı rikâbından cihânı kıldı nûrânî

Yine ol sancak-1 zerrîn-ser ü sîmîn-kabâ kıldı

Livâ-yı subh-ı nûrânî gibi rûşen bu eyvânı

Cihân emn ü amân buldı yine şemşîr-i pûlâdın

Belâ Ye'cûc'ına sedd eyledi İskender-i sânî

Bakî’nin Sadrazam Alî Paşa için söylediği Bahâriye'den birbirini izleyen 3 beyit de (Küçük 1994: 39) şöyledir:

Döşedi yine çemen nat'-1 zümürrüd-fâmın

Sîm-i hâm olmış iken ferş-i harîm-i gül-zâr

Yine ferrâş-1 sabâ sahn-1 ribât-1 çemene

Geldi bir kafile kondurdı yüki cümle bahâr

Leşker-i ebr çemen mülkine akın sald

Turma yağmâda yine niteki yağı Tâtâr

Yine Bakî̀nin Sünbül Kasidesi'nin nesîbinde "yine" belirtecini, geçmişle şimdiki zaman arasında kurduğu ilgiyle eskiyi anımsatıp vurgulama, yaşanılan dönemi pekiştirip güçlendirme gibi işlevlerle kullandığ beyitler (Küçük 1994: 62-63):

Oldı gül-şen yine bir dil-ber-i müşgîn mergul

Şol kadar virdi ana zînet ü zîver sünbül

Yine gömgök tere batmış çıka geldi çemene

Nev-bahâr irdi diyü virdi haberler sünbül 
Yine Fir‘avn-i şitâ ceyşine Mûsâ-mânend

Eyledi elde asâsını bir ejder sünbül

Sâkiyâ zevrakı sür bâd-1 bahâr esdi yine

Sebze-zâr oldı yem-i ahdar u lenger sünbül

Bürüdi kendinün etrâfını bâl ü per ile

Yine tâvûs-sıfat cilveler eyler sünbül

Yine ferrâş-sıfat destine cârûb almış

Ki ide hidmet-i hâk-i der-i dâver sünbül

Nef'î́nin Sultan I. Ahmet'e sunduğu Bahariye'den beyitler (Dî̀ân 1252: Kas. s. 9):

Bahâr irdi yine düşdi letâfet gül-sitân üzre

Yine oldı zemînün lutfı galib âsmân üzre

Yine her lâle bir şem'-i muanber yakdı dûdından

Sehâb-1 anber-efşân oldı peydâ bûstân üzre

Yine çıkdı beyâza nakşı her serv-i gül-endâmun

Sarıld $\imath$ yâsemen şâh-1 nihâl-i ergavân üzre

Nef' $\hat{\imath}^{\prime}$ nin Şeyhülislam Mehmed Efendi için söylediği Bahariye'nin ilk iki beytinin söyleyiş kalıbı, yukarıdaki Kaside'nin ilk iki beytinde olduğu gibi (yüklem+belirteç)/ (belirteç+yüklem) çaprazlaması içerisinde söylenmiştir (Dî̀ân 1252: Kas. s. 116):

Bahâr irdi yine bâğa döşendi nat'-1 jengârî

Yine sultân-1 gül itdi müşerref taht-1 gül-zârı

Yine bâd-1 sabâ üftân u hîzân irdi gül-zâra

Dem-i Îsâ-veş ihyâ eyledi ezhâr u eşcârı

Nefî̀nnin Veziriazam Nasûh Paşa için söylediği Temmûziye 'nin ilk iki beyti (Dîvân 1252: Kas. s. 73) şöyledir:

Yine irişdi temûz old $\imath$ cihân pür-tef ü tâb

Girdi bir hilkate hep âteş ü bâd âb ü türâb

İrdi bir gayete te'sîr-i hevâ kim bir mûr

Bir dem-i germ ile eyler yedi deryâyı serâb 
Şeyh Galib'in çok ünlü bir gazelinin aşağıdaki beyitleri de "yine" belirtecinin özgün kullanışının çok güzel örneklerindendir:

Yine zevrak-1 derûnum kırılup kenâra düşdi

Dayanur $\mathrm{m} 1$ şîşedür bu reh-i seng-sâra düşdi ${ }^{14}$

Erişüp bahâra bülbül yenilendi sohbet-i gül

Yine nevbet-i tahammül dil-i bî-karâra düşdi

Bütün bu yetkin örneklerin yanında, Fuzulî́nin Bağdat Valisi Ayas Paşa övgüsünde söylediği kaside de bu konu açısından çok güzel üslûp özellikleriyle doludur. Kasidenin ilk 3 beytinin her dizesinde "yine" belirteci yinelenerek öncelenmiştir:

Yine kıldı sabâ gül-zâra da'vet bülbül-i zârı

Yine kumrî makam itdi fezâ-yı sahn-ı gül-zârı

Yine düşdi hevâdan sebze-zâra katre-i şeb-nem

Yine gül-zâra saldı zıll-i rahmet ebr-i âzârı

Yine dîvâne-i 1şk eyledi dârü'ş-şifâ meyli

Yine gül-zâra çıhdı gûş̧e-i mihnet giriftârı (s. 68)

$\mathrm{Bu}$ beyitlerin dizelerinde, Ayas Paşa'nın "karışıklık ve olumsuzluklarla dolu bir ortama tek kurtarıcı ve koruyucu olarak gelişi nedeniyle duyulan sevinci" vurucu bir biçimde yansıtmak amacıyla, aynı "yine" sözünün karşılığında 6 ayrı eylemin (kıldı, itdi, düşdi, saldı, eyledi, (̧ıһdı), Paşa'ya ilişkin türlü mecazlarla birlikte anlamsal ve söz dizimsel bir koşutluk oluşturacak biçimde kullanılması, yapısal açıdan öz-biçim bütünlügünü gösteren ilginç bir üslûp özelliğidir. Daha yalınlaştırarak söylemek gerekirse, karışıklığın çokluğuna karşılık, kurtarıcının büyük gücü ve halkın beklentisinin düzeyi çok dengeli bir söz yapısıyla verilmiştir. Yine Ayas Paşa'nın övgüsünde söylenmiş ve aşağıda 4. maddede söz konusu edilen Kaside'nin ilk 4 beytinde de buna çok benzeyen bir üslûp özelliği sergilenmiştir. Bu Kaside'de öncelenen aynı "geldi" eylemiyle de, özelliklerine bağlı olarak Paşa'nın ilişkilendirildiği (Îsî, Hızr,

${ }^{14}$ Şeyh Galib'in bu gazeli Hammâmî-zâde İsmail Dede Efendi tarafından mahur makamında bestelenmiştir. Bu nedenle, aşağıda verilen şarkı örnekleri arasında da düşünülebilir. 
Mehdî, Âsâf) dinî kimlikleri ve kutsal kişilikleri nedeniyle onların toplumda ve insanlar üzerinde etkin olmuş üstün işlevlerine telmih yoluyla gönderme yapılmıştır.

Yukarıdaki beyitlerin arkasından Fuzulî birkaç beyitle kendi durumundan yakınır, bunlardan sonra da Paşa'nın övgüsüne geçmeden önce şu beyitle (14. beyit) tekrar Kaside'nin ilk beytinde yaptığ1 gibi "bülbül"e seslenir ve "Sen güle kavuştun, bana da Paşa'nın yüzü nasip olsun." diyerek Paşa'nın övgüsüne geçer:

Yine ey bülbül-i bî-çâre eyyâm-1 bahâr old

İrişdi vakt kim baht ola ehl-i derd gam-hârı

"Yine" belirtecinin divan şiirinde kullanımının yaygınlığının nedeni, bu belirtecin insanlara, çok geniş bir zaman dilimi içerisinde yaşanan anılarına ve yaşam deneyimlerine çağrışım olanağı verdiği ve bunları hayallerinde yeniden yaşama ortamı hazırladığı içindir. Aynı görevi daha duygusal bir yönden olmak üzere şarkılar da yapmaktadır. "Yine" öncelemesiyle söylenmiş pek çok şarkı güftesi bulunmaktadır. Bu şarkıların sevilmesinde bestelerinin güzelliği başta gelmekle birlikte, bu öncelemenin uyandırdığı duygusal yoğunluğun ve çağrışım zenginliğinin etkisi de unutulmamalıdır. Divan şiirindeki örnekleri desteklemek amacryla birkaç ünlü şarkı güftesinin ilk dizeleri şöyledir:

a. Mevsim başlangıcını gösteren yine belirteçli öncelemeler: Bu konudaki "yine" öncelemeleri aşağıdaki örneklerde olduğu gibi genellikle, mevsimlerin gelişiyle ortaya çıkan olumlu ve olumsuz durumların yeniden yaşanacağını vurgular:

-Yine bahâr oldu coştu yüreğim

Akar boz bulanık selli dereler

-Yine bir bâd-1 hazân esti güzel bahçemize

Yine bir başka bahâr hasreti düştü bize

b. Olay başlangıcını gösteren yine belirteçli öncelemeler: Bu türlü "yine" öncelemeleri de genellikle, daha önce yaşanmış, benzeri baştan geçmiş bir olayla yeniden bir kez daha karşılaşıldığını anlatır:

-Yine bağland $\imath$ dil bir nev-nihâle

Misâli gelmez âlemde hayâle 
-Yine bir gül-nihâl ald $\imath$ bu gönlümü

Sîm-ten gonca-fem bî-bedel bir güzel

-Yine düştü gönül bir dil-figâre

Gam-1 aşkıyla sînem pâre pâre

-Yine neş'e-i mahabbet dil ü cânım etti şeydâ

Yine bezm-i ayş-i vuslat idüp ehl-i aşkı ihyâ

c. Durum başlangıcını gösteren yine belirteçli öncelemeler: $\mathrm{Bu}$ "yine" öncelemeleri de genellikle, daha önceden bilinen bir durumla beklenmedik bir anda karşılaşılmasını belirtir:

-Yine bu yıl Ada sensiz içime hiç sinmedi

Dil'de yalnız dolaştım hep göz yaşlarım dinmedi ${ }^{15}$

-Yine bir sızı var içimde akşam oldu diye

Gözüm acıyor ağlarım hâlâ bilmem niye

"Yine" belirtecinin semantik ve stilistik kullanımı açısından yakın bir benzeri belirteç de "hani"dir. Konuşma dilinde de kullanım sıklı̆̆ı (frequency) oldukça yüksek olan "hani" belirteci de "yine" belirtecinin yazılı ve sözlü kullanımlarında olduğu gibi genellikle geçmişe gönderme yapılarak, geçmişte yaşanmış bilinen bir olayı, durumu ya da geçmişte verilmiş bir sözü anımsatacak ${ }^{16}$ bir biçimde öncelendiği görülmektedir. Tevfik Fikret'in "ulu bir ağaç" metaforuyla "vatan"1 anlattığ1 Çınar adlı şiiri de (Dilçin 2005: 411-412) konuşma dili doğallığı içerisinde "hani" belirteciyle başlamaktadır. Bu önceleme, bu başlangıç, şiir dili açısından yadırganacak bir kullanım olmak yerine, günümüzden gerilere uzanan yani Osmanlı Devleti'nin kuruluşu, İmparatorluk oluşu ve şiirin yazıldığı yıllardaki durumunu kapsayan bir zaman dilimi açısından yoğun bir duygu ve düşünce çağrışımlarına yol açmaktadır:

Hani bir gün seninle Topkapı'dan

Geliyorduk; yol üstü bir meydan,

${ }^{15} \mathrm{Bu}$ şarkının sözlerinde geçen Ada ve Dil yer adları, İstanbul'un toplumsal ve kültürel yaşamında önemli bir yeri olan Büyükada'yı ve yine Büyükada'da âşıkların, çamlarının altında diz dize oturup denizi seyrettikleri ve el ele tutuşup gezindikleri Dil Burnu'nu anlatmaktadir.

${ }^{16}$ Türkçe Sözlük, TDK Yay., 10. bas., Ankara 2005, s. 843. 
Bir çınar gördük: Enli, boylu, vakur

Bir ağaç; hiç eğilmemiş, mağrur

Koca bir gövde, belki altı asır,

Yusuf Nalkesen'in bestesi olarak gönüllerde yaşayan bir şarkının sözleri de Orhan Seyfi Orhon'un"un "hani" belirtecinin öncelendiği bir şiirine dayanmaktadır. Bu önceleme o denli doğal bir söyleyiş içerisinde yapılmıştır ki, sevgiliden olası bir ayrılık durumunda önceden belirlenmiş davranış biçimlerinin olayın şiddeti karşısında uygulanamaması açısından duyulan acı "sitem"i vurgulaması, şiiri okuyanlar ve şarkıyı dinleyenler üzerinde derin bir duygu coşkunluğu yaratmaktadır:

Hani, o birakıp giderken seni,

Bu öksüz tavrını takmayacaktın.

Şiirin son dizesinde yine "hani" sözü öncelenerek kişileştirilen "göz yaşı" na seslenilmesi, birinci dizedeki öncelemeyi, yineleme (tekrîr, tekrar) sanatı açısından pekiştirdiği gibi, "göz yaşı"nın "sözünde durmayışını" da çok duygulu bir "sitem"le vurgulamaktadır:

Hani, ey göz yaşım akmayacaktın!

Fuzulî’nin şiirlerinde yüklem öncelemesi örnekleri ve bunların değerlendirilmelerine geçmeden önce, Hacı Ârif Bey'in hicaz makamındaki eşsiz bir şarkısının ${ }^{17}$ güftesini sunmak istiyorum. Çok kısa olarak değinmek gerekirse şarkı güftesinin dizelerinde şair, bir "av" metaforuyla sevgili-âşık arasındaki tek yönlü aşk ilişkisini, avcl-av arasındaki avlanma olayıyla özdeşleştirerek, örtüştürerek ortaya koymuştur. Bu nedenle ilk 4 dizenin, yüklem+nesne/tümleç+özne sırasıyla devriklenerek dizeler arası bir koşutlukla birbirini izlemesi, dize başlarındaki yüklem öncelemelerini (avlama, bağlama, büyüleme, saplama) anlamsal yönden güçlendirerek şarkıya, dinleyenlerin deyim yerindeyse ciğerlerini delip geçen bir etkinlik ve derinlik katmaktadır. Bunun yanı sıra, âş̧ıın edilgen bir tek "gönlü"ne

17 Hacı Ârif Bey'in bu şarkısı, çocukluğumdan beri bu yaşıma gelinceye kadar radyo ve TV'lerden, plak, teyp, kaset ve CD'lerden yüzlerce kez bıkıp usanmadan tekrar tekrar dinlediğim, kendi kendime mırıldandığım ve her dinleyişimde, her mırıldanışımda güfte ve bestesinin söz ve müzik değerleri açısından yeni bir estetik inceliğini sezerek duygulandığım olağanüstü güzellikte bir şarkıdır. 
karş1lık; sevgilinin etken dört güzellik öğesi olan göz, saç, bakış ve kaşının ceylan, sünbül, büyücü, hançer gibi benzetmeliklerle güçlü/gü̈csüz karşıtlığı oluşturularak verilmesi, yapısal açıdan doğal olarak sevgilinin önde olma durumuna okuyanı ve dinleyeni odaklandırmaktadır:

Sayd eyledi bu gönlümü bir gözleri âhû

Bend eyledi zencîre beni sünbül-i gîsû

Bilmem ki ne sihr eyledi ol gamze-i câdû

Saplandı ciğer-gâhıma dek hançer-i ebrû

Hûrî mi aceb nûr-1 mücessem mi nedir bu

$\mathrm{Bu}$ beş dizede içerik yönünden "ne söylendiği"ni derinleştirip etkinliğini artıran ve bunun sonucunda yoğun bir duygu coşkunluğu sağlayan "nasıl söylendiği" konusuna stilistik açıdan yukarıda gösterilen ölçütlere ek olarak birkaçını daha kısaca sıralamak istiyorum: Öncelemeler, dikey ilişkiler açısından cümle öğelerinin koşutluğu, farklı eylem ve sıfatları birbirini destekleyerek arka arkaya yineleme, söz ve anlam ilişkileri açısından denge ve orantı, di'li geçmiş zamanın eskilik ve kesinlik anlatmasına karşın kuşkulu söylem (bilmem ki) kullanma, "sayd eyledi, bend eyledi, sihr eyledi, saplandı" eylemlerinin gerçekliğini "... mi aceb, ... mi nedir" sorularıyla pekiştirme, özne ve yüklem arasındaki eylem uyuşması, "bu" kelimesinin hem gösterme sıfatı olarak ilk dizede "âşık"1 hem de son dizede işaret zamiri olarak "sevgili" yi karşıtlayarak vurgulama, güftenin kafiyeleri olan "-û" sesleriyle "âşık" ve "sevgili" kavramlarının göstergesi olarak kullanılan söz konusu iki "bu" kelimesini ses ve anlam yönünden pekiştirerek ilgiyi bu kavramlar üzerine yönlendirip yoğunlaştırma, yine sevgilinin 4 güzellik öğesine ilişkin kelimelere bağlı olan aynı kafiye sesleriyle, sevgilinin sıfatlarını anlatan "hûrî" ve "nûr" kelimelerindeki " $r$ " ile birlikte " $\hat{u}$ " sesleri arasında kurulan aliterasyonla sevgilinin güzelliğinin vurgulanması... Müzik yönünden şark1nın etkinliğini artıran bence çok önemli iki nokta da şudur: Prozodi yani söz ve anlamin besteyle olağanüstü uyuşması, bestede "gözler, sünbül, gamze, hançer" kelimelerinin "göz-, sün-, gam-, han-" hecelerinin yinelenerek ve yükselen bir ezgiyle vurgulanarak okunması... bu okuyuşla sevgilinin güzellik öğelerinin (gözler, sünbül, gamze, hançer) ve sevgilinin yüceltilmesi... 
Fuzulî’deki yüklem öncelemelerine geçmeden önce şu noktayı özellikle belirtmekte yarar görüyorum. Yukarıda gösterilen önceleme örneklerine daha pek çok ilginç örnek kolaylıkla eklenebilir. Bu yazı içerisinde verilen örnekler de zaten öncelemelerin bir türü olan sözdizimsel öncelemelere ilişkindir. Öteki önceleme türleri de ele alınıp incelendiğinde çok zengin bir kaynağın ortaya çıkarılacağında hiç kuşku yoktur. Böylece divan şiirinin stilistik açıdan taşıdığı güzelliklerin ve değerlerin bir bölümüne ulaşılmış olacaktır. Daha önce de belirtildiği gibi, yalnızca divan şiiri üzerine değil, halk şiiri üzerinde bu yönde yapılacak çalışmalar da halk şiirinin dili ve anlatımına, doğallığı ve güzelliğine hiç kuşkusuz çok şey katacaktır.

Fuzulî’nin özellikle kasidelerinde gerçekleştirdiği yüklem öncelemeleri, bunlara daha ayrıntılı olarak yaklaşılabilirse de genel bir çizgiyle dönem, olay, durum, kişi ve kavram belirtme amacına dayanmaktadır. Örneklerin genellikle kasidelerden seçilmesinin nedeni, öncelemelerin özellikle kasidelerin matlalarında ya da matlaı izleyen birkaç beyitte yapılanlarının kasidenin konusuyla, konuya ilişkin motifleriyle, kompozisyonuyla doğrudan ilişkili olması, biçim-öz, yapı-anlam kaynaşması ve bütünleşmesinde başka etkenlerle birlikte önemli bir işlevi olması nedeniyledir.

\section{Dönem belirten yüklem öncelemeleri:}

Fuzulî’nin Kanuni Sultan Süleyman'a sunduğu Gül Kasidesi, türlü özellikleriyle kaside boyunca betimlenecek olan "gül"ün açılarak kazandığ1 yeni durum, dize başlarına çekilmiş, yani öncelenmiş "çıhdı" ve "sald1" eylemleriyle ${ }^{18}$ (1. beyit) vurgulanarak başlamaktadır. 3. ve 4 . beyitlerde de bahar mevsiminin geldiği, yani yeni bir "dönem"e girildiği

${ }^{18}$ Rahmetli Prof. Dr. Tunca Kortantamer de, Fuzulî’nin söz konusu Kaside'sini, ağırlıklı olarak anlam-yapı ilişkisi, biçim-öz kaynaşması açısından ele aldığı makalesinde ("Gül Kasidesi", Eski Türk Edebiyatı Makaleler-I, Akçağ Yay., Ankara 1993, s. 413-435), Kaside'nin şiirselliğinin oluşmasında dilsel öğelerin düzenlenmesi konusuna da değinmiştir. Prof. Kortantamer bu makalesinde özellikle, Kaside'nin ilk birkaç beytindeki yüklemler ve öteki dilsel öğelerin şiir-dil bütünlügüünü oluşturmadaki işlevleri üzerinde durmuş, Fuzulî́nin şiirlerinden yansıyan güzel ve güçlü Türkçe söyleyişe "bilhassa devrik cümleler"in katkısı açısından yaklaşarak özlü değerlendirmeler (s. 431-434) yapmıştır. 
"Geldi ol dem kim...", "Yetdi ol mevsim ki..." biçimindeki yinelemeli öncelemelerle belirtilmektedir. 3. ve 4 . beyitlerin başında yer alan ve yukarıda tırnak içerisinde verilmiş söylemlerdeki "gösteren"ler farklı sözler de olsa "gösterilen" aynıdır. Bu söylemlerdeki gelmek/yetmek ve dem/mevsim sözleri yakın anlamlı kelimeler olmaları nedeniyle aynı kavramı, "ulaşılan yeni dönemi" " bahar" 1 anlatmaktadır. Divan şiirinde, aynı kavramın eşit ya da yakın anlamlı kelimelerle anlatıldığı yukarıdakine benzer yüzlerce güzel örnek gösterilebilir. Böyle durumların, yani aynı kavramı değişik söylemlerle, bir öncekinden ayrı imiş gibi algılanabilecek ya da öyle bir izlenim birakabilecek anlatımlarla yineleyen önceleme kalıplarını, gereksiz bir tekrar olarak görmekten kaçınarak, stilistik açıdan şiire etkileyici bir yoğunluk katan üslûp öğeleri olarak değerlendirmek daha uygun olacaktır. Çünkü, gelmek/yetmek ve dem/mevsim sözlerinin anlamları birbirine yakın olmakla birlikte birbirinden farklı çağrışımlar yaratmaları nedeniyle gözde ve düşüncede canlandırılmaya çalışllan imgeyi renklendirip zenginleştirmektedir.

Çıhdı yaşıl perdeden arz eyledi ruhsâr gül

Saldi ${ }^{19}$ mir ât-1 zamîr-i pâkden jengâr gül

Geldi ol dem kim ola izhâr-1 hikmet kılmağa

İnşirâh-1 sadr ile sadr-1 saf-1 ezhâr gül

Yetdi ol mevsim ki açmağa gönüller mülkini

Ola gül-şende reyâhin hayline ser-dâr gül (s. 37)

"Goncanın yeşil kabuklarının açllıp gülün yüzünü göstermesi" olgusunu anlatmak amacıyla 1 . beyitte öncelenen "çıhdı" eylemi, Ka-

${ }^{19}$ TD'de "saldı" sözü yerinde "sildi" varyantı bulunmaktadır. Prof. Dr. Tahir Üzgör bir makalesinde, konuya ilişkin olarak yaptığı araştırmaların sonucunda, doğru varyantın "saldı" eylemi olması gerektiğini gerekçeleriyle göstermiştir. Bkz. "Fuzûlî́yi Anlamak", Selçuk Üniversitesi Türkiyat Araştırmaları Dergisi, sayı 3, Konya 1997, s. 87-101. (Ayrıca, Gül Kasidesi'nin bu ilk beyti, Fuzulî́nin, Divan'ından Hadîkat's-Sü'edấ'ya aktardığı beyitler arasında da bulunmakta ve orada da "saldı" varyantıyla geçmektedir. Bkz. Şeyma Güngör, Kültür ve Turizm Bakanlığ1 Yay., Ankara 1987, s. 47.) Prof. Üzgör de yukarıdaki makalesinde ayrıca, genel olarak Fuzulî́nin şiirlerinde ve özel anlamda da Gül Kasidesi'nde bir üslûp konusu olmak açısından eylemlerin taşıdığı öneme ana çizgilerle kısaca değinmiştir (s. 94-95). 
side'nin 7,8 ve 9. beyitlerinde de başka imgeleri anlatmak amaciyla birkaç kez daha yinelenmiştir. Bu durum şaire, "gül"ü kişileştirerek "çıkmak" kavramına ilişkin olarak bazı dinî konulara telmihler yapma yolunu açmıştır. Başka bir deyişle "çıkmak" eylemi, Kaside'yi bu açıdan çeşitlendiren temel bir üslûp öğesi olarak kullanılmıştır. (Aşağıda 5 . maddede değerlendirilen Su Kasidesi'ndeki "saçmak" eylemi de aynı stilistik özelliği yansıtmaktadır.) Kaside'nin beyitleri incelendiğinde pek çok beyitte "çıkmak" eyleminin anlamina ilişkin olarak açılmak, ayrılmak, gitmek, uzaklaşmak, sikıntıdan kurtulmak, özgür kalmak, değişmek, ulaşmak, erişmek, artmak, oluşmak, gerçekleşmek, göstermek, görünmek, gizlemek, saçmak, aydınlatmak, yakmak.... gibi kavramlara gönderme yapıldığ1 ya da bunların anıştırıldığ 1 görülecektir.

Fuzulî’nin Hz. Ali'nin övgüsünde söylediği kaside de yine benzeri bir "dönem" başlangıcını vurgulayan şu matla ile başlamaktadır:

İrişdi vakt ki fasl-ı hazân-ı nâ-hem-vâr

Kıla su tek harekâtın müzâhim-i eşcâr (s. 29)

Bu beyitteki öncelemelerle de "hazân mevsimi" nin gelişiyle bunun sonucunda gelişen olaylara gönderme yapılmıştır.

$\mathrm{Bu}$ konuyu başarılı örneklerle çeşitlendirmek amacıyla Ahmed Paşa'nın ve Nef'î́nin iki kasidesine değinmek uygun olacaktır. Ahmed Paşa'nın Sultan Bayezid'e sunduğu bir kasidede arka arkaya eylem (yüklem) kullanma (geldi, oldı, açdı, düzdi), nicelik ve nitelik yönünden "çokluk" kavramını anlatmak içindir. Bu kullanma, aynı zamanda biçim-öz kaynaşmasının oluşmasında da etken olmaktadır. Kaside'nin ilk iki beytinde biçimsel açıdan 4 eylemin öncelenmesiyle öz açısından bu eylemlerle ortaya çıkan sonucun çeşitliliğine gönderme yapılmaktadır. Baharın gelişiyle doğanın kazandığı canlılık ve güzelliğin "çokluk"u bu yüklem öncelemeleriyle daha etkileyici bir boyut kazanmaktadır:

Geldi bir dem kim bezendi dürlü reng ile zemîn

Oldı ferrinden bahârun bâğ firdevs-i berîn

Açdı anber hokkasın sahrâda attâr-1 sabâ

Düzdi rengîn câmesin bustânda bezzâz-1 zemîn (Tarlan 1966: 
Nef'î́nin IV. Murat'a sunduğu ünlü Bahâriye'sinin ilk iki beyti de "baharın gelişi"ni anlatan eylemlerin öncelenmesiyle (Dîvân 1252: Kas. s. 35), yani "dönem" belirten güzel bir yüklem öncelemesiyle başlamaktadır. Bu beyitlerdeki "esdi" ve "erdi" eylemlerinin öncelendiği dizelerde, aynı -di'li geçmiş zaman kipinde "açıldı" ve "oldı" eylemlerinin de kullanılması, öncelemeleri nicelik ve nitelik yönünden de ayrıca desteklemektedir. Bu arada 1. beytin 2. dizesinde "açsun" dilek-emir kipindeki yüklemin öncelenmesi de göz ardı edilmemelidir. "Güller açıldı", bunun karşılığında "gönüllerimiz de açılsın" koşutluğu, bu öncelemeyle etkileyici bir neden-sonuç ilişkisi içerisinde verilmiştir. Bu koşutlukla anlatılan doğanın insanı etkilemesi ve bunun sonucunda ortaya çıkan $d \iota s ̧$ dünya/iç dünya dengesi, "esdi" ve "erdi" eylemlerinin kullanım biçimiyle daha güçlü bir nitelik kazanmıştır:

Esdi nesîm-i nev-bahâr açıldı güller subh-dem

Açsun bizüm de gönlümüz sâkî meded sun câm-1 Cem

Erdi yine ürd-i behişt oldı hevâ anber-sirişt

Âlem behişt-ender-behişt her gûşe bir bâğ-1 îrem

\section{Olay belirten yüklem öncelemeleri:}

Bu türlü yüklem öncelemelerinde de yine ön planda gerçekleşen olay anlatılmakla, betimlenmekle birlikte arka planda bu yeni olayın yol açtığı sonuçlar söz konusu edilmektedir. Örneğin ön planda "baharın gelişi" anlatılırken, arka planda "övülen kişinin gelişi"yle beklentilere türlü göndermeler yapılmaktadır.

Fuzulî’nin Bağdat ve Şam Beylerbeyliği de yapmış olan Lala Cafer Paşa'nın övgüsünde söylediği Kaside'nin ilk 5 beyti şöyledir:

Kıldı def'-i gam dil-i uşşâkdan zevk-i bahâr

Âh kim gösterdi 1şk ehline devrân hecr-i yâr

Sâkin-i hum-hâne peydâ kıldı şevk-i seyr-i bâğ

Geldi ol dem kim kıla bî-çâreler terk-i diyâr

Saldı göz gird-âbına nezzâre-i gül mevc-i hûn

Kıldı dil âyînesin pür jeng zevk-i sebze-zâr 
Gonce tek çâk oldı ceyb-i sırr-1 erbâb-1 afâf

Aldı meyl-i seyr-i gül-zâr ehl-i temkinden vakar

Dutdı câm-1 lâle-gûn erbâb-1 işret gül görüp

Kan içürdi halka nîreng ile çerh-i hîle-kâr (s. 91-92)

Kasidenin 15 ve 16. beyitlerinde de koşut ve yarı koşut iki beyitte 4 yüklem (ideler, olalar, dutalar, ideler) öncelenerek olay vurgulanmıştır. Bu Kaside'nin vezni fâilâtün fâilâtün fâilâtün fâilün'dür. Bu beyitlerde öncelenmiş 4 yüklemin (ideler, olalar, dutalar, ideler) ilk hecelerinin açık olması nedeniyle buralarda imale yapmak gerekmektedir. Birbirini izleyen bu 4 dizenin başında yapılan bu imaleleri bir aruz kusuru olarak değil, gerçek bir ses sanatı olarak değerlendirmek gerekir. Anlam açısından birbirine bağlı bu 4 yinelemeli yüklem öncelemesi, yapılması gerekenlerin ne denli zorunlu olduğunu belirtmesinin yanı sıra, bu eylemlerin ilk hecelerinde birbirini izleyen imaleler ${ }^{20}$ de "abartma vurgusu"yla yapılması gerekenlerin mutlak ve kesinliğini ses yoluyla anlatmaktadır:

${ }^{20}$ Birbirini izleyen bu imaleler bana, Nedim'in benzer özellikler taşıyan şu beytini (Gölpınarlı 1972: 297) anımsattı:

Döğ̈̈lmeğe söğülmeğe koğulmağa bi’llâh

Hep kailüm ammâ ki efendim senün olsam

Bu beytin vezni mef' ûlü mefâîlü mefâîlü faûlün'dür. Beytin ilk dizesinde arka arkaya gelen 3 eylemin ilk hecelerinde ( $(\ddot{0}-$, sö-, ko-) imale yapılmaktadır. Bu hecelerdeki gerektiği kadar uzatmaya uygun 3 yuvarlak ünlünün yarattığı abartılı ses yoğunluğu, kulun efendisine, âşığın sevgiliye karşı yalvarış ve yakarışlarını yansıtmaktadır. Bu imalelerin doğurduğu yalvarış ve yakarış tonu, hiç kuşkusuz böyle bir söz düzenlenişinden ve o yönde bir söz, eylem ve yapı seçiminden ileri gelmektedir. Bu nedenle, bu eylemlerde yapılan imaleler bir aruz kusurundan çok bir ses ve anlam sanatı değeri taşımaktadır. Nedim bu imalelerle, efendisinin olması karşılığında ona gönül rızasıyla boyun eğeceğini ve onun her türlü eziyetine katlanabileceğini, birbirini izleyen bu ses vurgulamalarıyla, bu 3 eylemin üstüne basa basa anlatmaktadır. (Beyitteki "koğulmağa" sözü yerinde Gölpınarlı'da "kul olmağa" varyantı bulunmaktadır; benim yeğlediğim varyant ise Gölpınarlı'da aparatta gösterilmiştir. Bu varyant, Halil Nihat Boztepe'nin hazırladığı Nedim Divanı'nda da "koğulmağa" biçimindedir. (İstanbul 1338-1340, s. 190) Bence de doğrusu bu olmalıdır. Çünkü, efendisinin, sevgilinin "kulu olmak" âşık için bir amaçtır, onur ve mutluluk verici bir ayrıcalıktır. Bu nedenle, divan şiiri açısından bakıldığında "kul olmak" isteği, "dövülmek" ve "sövülmek" kavramlarıyla bir arada kullanılabilecek eş değer nitelikte bir kavram değildir. Divan şiirinde işlenen efendi/kul=sevgili/âşık ilişkisini ancak birbiri arkasına gelen söz konusu bu 3 
İdeler gafillere tekmîl-i esbâb-1 gurûr

Olalar âriflere manzûr-1 ayn-1 i'tibâr

Dutalar bir dem karâr ammâ yine dil-gîr olup

İdeler ser-menzil-i ma‘hûda dünyâdan firâr (s. 92)

Baharın gelmiş olmasına karşın Bağdat'ın güvenliksiz ortamının bu duruma gölge düşürmesi nedeniyle Cafer Paşa'ya bir kurtarıcı olarak umut bağlanılması, olayların çokluğunu simgeleyen arka arkaya yapıl-

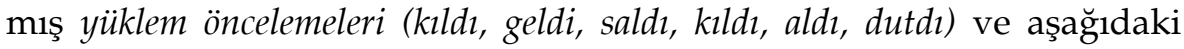
koşut söyleyişlerle anlam-yapı kaynaşması gerçekleştirilerek yansıtılmıştır. Kasidenin kompozisyonu içerisinde yer alan durum/beklenti/uygulama aşamaları bu türlü yapısal yaklaşımlarla öne çıkarılarak güçlü bir biçimde verilmeye çalışılmıştır:

Ol felek-rif'at ki râyındandur istihkâm-1 mülk

Ol melek-sîret kim andandur revâc-1 rûzgâr

Çeşme-i lutfından itmiş bahr tahsîl-i sehâ

Nâ'ib-i kudretden almış çerh ref'-i iktidâr

Devr tavr-1 dil-güşâ kilkinden itmiş iktisâb

Çerh mihr-i bî-riyâ hulkından itmiş müste âr (s. 92)

Fuzulî’nin İbrahim Paşa için söylediği bir Kaside'sinin matlaı da şöyledir:

Götürdi bâd burka' çihre-i gül-berg-i handândan

Getürdi âlemi mürg-1 çemen feryâda efgandan (s. 85)

$\mathrm{Bu}$ beytin dize başlarındaki götürdi /getürdi yüklemleri, bu eylemler arasındaki anlam açısından karşıtlığı ve dizeler arasındaki neden/sonuç bağıntısını güçlendirme amacıyla öncelenmiştir. Bu güçlendirmede eylemlerin aynı çekimde olmaları ve dize başlarında koşut bir söz düzeni içerisinde bulunmaları da etken olmuştur. Birbirini izleyen yani biri ol-

eylem yansıtabilir. Çünkü divan şiirinde âşık, sevgiliden sürekli olarak eza cefa görür, horlanıp azarlanır, itilir kakılır. Bu açıdan bakılınca, "dövülmek, sövülmek, kovulmak" eylemleri uygulamada birbirine bağlı, birbirini izleyen eylemlerdir. $\mathrm{Bu}$ nedenlerle Gölpınarlı'daki "kul olmağa" varyantı beytin mazmununa uymamaktadır. Nedim kısaca, "Efendim! Tek senin kulun olayım, vallahi dövülmeye de sövülmeye de kovulmaya da her şeye razıyım." demek istiyor.) 
mazsa öteki gerçekleşemeyen "gülün açılması-bülbülün (gülü görerek) feryada başlaması" sürecinin mantıksal sırası bu türlü bir söyleyişle kesinlik kazanmaktadır. Eğer 2. dizesi aşağıdaki biçimde söylenmiş olsaydı, bu durumda beytin belirtilen söz düzeninin etkisi büyük ölçüde yok olacağı gibi, her iki dizedeki cümle yargısı da biri ötekinin nedeni/sonucu olma özelliğini yitirerek sanki bağımsız birer cümle durumuna düşecekti:

Çemen mürg1 getürdi âlemi feryâda efgandan

Fuzulî̀nin bir gazelinin aşağıdaki matlaında da, "sevgilinin gelişi" "gelür" yani 'geliyor' yüklemiyle belirtilip öncelendikten sonra, "serv, gül ve lâleye açılmaları", "meh ve mihre doğup çıkarak sevgiliye bakmaları" "açılun, çıhun, nezzâre kılun" emirleriyle anlatılmıştır:

Gelür ol serv-i sehî ey gül ü lâle açılun

V'ey meh ü mihr çıhun kudrete nezzâre kılun (s. 283)

Gazelin 2. beytinde de sevgilinin "bâğa geleceği" bir kez daha pekiştirilerek, güllerin toplanıp bir araya gelmeleri ve sevgilinin yoluna "altın saçmaları" "ide gelün, yığılun, derilün" eylemleriyle buyurulmuştur. 2. beyit de şöyledir:

Azm-i bâğ eylemiş ol serv-i revân ey güller

Zer nisâr ide gelün cümle yığıllun derilün

Bu beyitlerde "konuğun gelişi, güzel giysiler giyilmesi, ortamın hazırlanması, herkesin toplanıp konuğu saygıyla karşılaması, ağırlanıp konukseverlik gösterilmesi" olayı türlü metaforlarla anlatılmıştır. Böyle bir olayın ekseni durumunda olan kişi hiç kuşkusuz "konuk"tur. Bu nedenle sözün anlatımında sevgilinin "geliş"i, "gelür, azm eylemiş" yüklemleriyle ilk sırayı almıştır. Sevgiliyi "karşılama" ise karşılayanlara 6 emir yüklemiyle bildirilmiştir. Bu durum, konuk/karşılayanlar, sevgili/âşıklar, tek/çok kavramlarını oluşturan ilk öğelerin önemi nedeniyle "gelür" öncelemesinin yapıldığını açık seçik olarak göstermektedir.

Fuzulî yine bir gazelinin aşağıdaki beytinde olduğu gibi, "gönlü" üzerinde yapılan işlemleri anlatan "bırahmış" ve üleşdürmiş" yüklemlerini önceleyerek, sevgilinin kendisine reva gördügü eziyetin düzeyini ve çokluğunu 2 eylemi bir arada kullanarak belirtmeye çalışmıştır: 
Bırahmış itlerine pâre pâre gönlümi ol meh

Üleşdürmiş kesüp erbâb-1 istihkaka kurbânın (s. 348)

Fuzulî́nin bir gazeli de şu matla ile başlamaktadır:

Olur ruhsâruna gün la'lüne gül-berg-i ter âşı

Sana eksük degül gökden iner yirden biter âşık (s. 276)

$\mathrm{Bu}$ beyitte de sevgilinin âşıklarının ne denli çok olduğu (7 beyitlik bu gazelin redifi "âşık"tır) vurgulanmak için "âşık olmak" deyiminin yardımcı eylemi öncelenmiştir.

Fuzulî’nin yine bir gazelinin matla beytinde de, "gönlün perişanlığ1"nın ve "mülkün viranlığı"nın "sevgili"ye ve "sultan"a sunulması "(arz) k1l" öncelemesiyle daha belirgin duruma getirilmiştir:

Kıl sabâ gönlüm perîşân oldugın cânâne arz

Sûret-i hâlin bu vîrân mülkün it sultâna arz (s. 263)

Fuzulî, bir gazelinin şu beytinde de "kılma" ve "eyleme" eylemleriyle "âh"ın kendisini nasıl bir yoğun etki altında bıraktığını anlatmıştır:

Kılma her sâat meni rüsvâ-yı halk ey berk-1 âh

Eyleme rûşen şeb-i gam külbe-i ahzânumı (s. 387)

Fuzulî, bir gazelinden alınan aşağıdaki beyitte yaptığ 1 "kıldı" ve "döymedi" öncelemelerini, ışka heves kılmak/derde döymemek kavramlarına bağlı olarak çohlar / men karşıtlığını vurgulamak için yapmıştır:

Kıldı Mecnûn kimi çohlar heves-i 1şk velî

Döymedi derde men-i bî-ser ü pâdan gayrı (s. 395)

\section{Durum belirten yüklem öncelemeleri:}

Yüklemin bildirdiği yargı, kişiyi ortaya çıkan yeni duruma ya da olaya hazırlar. Fuzulî́nin bir gazelinden aktarılan aşağıdaki beytinde, "servi boylunun gölgesi üzerinden gitti" o nedenle "içine düştüğün duruma ağla" denilerek, "sevgilinin gölgesinin etkisi"nin ve "karşılaşılan kötü durum"un âşık yönünden önemi öncelenen yüklemlerle belirtilmeye çalışılmıştır:

Gitdi başundan gönül ol serv-kaddün sâyesi

Ağla kim idbâra tebdîl oldı ikbâlün senün (s. 292) 
Yine Fuzulî'nin,

Dün sâye saldı başuma bir serv-i ser-bülend

Kim kaddi dil-rübâ idi reftârı dil-pesend (s. 443-446)

dizeleriyle başlayan 7 bentlik ünlü Müseddes'inin 6 dizesi sevgilinin türlü güzelliklerini betimleyen yüklem öncelemeleriyle başlatılmıştır. Müseddes'de belli aralıklarla yinelenen bu öncelemeler (egmiş, virmiş, salmış, tökmiş, yahmış, düşmiş), sevgilinin güzelliğinin etkinliğini türlü yönleriyle betimleyerek bunların geçmişte var olduğunu ve gelecekte de böyle sürüp gideceğini vurgulamaktadır. Söz konusu 6 eylem, aynı zamanda sevgilinin türlü güzellik öğelerinin bu yollarla ortaya çıkardığı sonuçlara karşı dolaylı yoldan bir hayranlık duygusu da uyandırmaktadır. Bu betimlemeler ayrıca, sevgili-âş̧ı ilişkileri açısından âşı̆̆ın nasıl bir kuşatma içine alındığına da gönderme yapmaktadır:

- Egmiş hilâli üstine tarf-1 külâhını (2. bend)

- Virmiş fürûğ şem'-i ruhı gün çerâğına

Salmış şikest serv-i kadi gül budağına (3. bend)

- Tökmiş gül üzre sünbül-i gîsû-yı müşg-bâr

Yahmış latîf ayagına gül-berg tek nigâr (4. bend)

- Düşmiş izârı üzre muanber selâsili (5. bend)

Bu beyitlerde ve benzeri kullanımlardaki öncelemelerle, -miş’li geçmiş kipinin dolaylı yoldan alınmış bilgileri anlatmaktan çok, anlatılan olaya, olguya, duruma tanık olunduğu, bunların doğrudan görülerek algılandığ1 daha öncelikli olarak belirtilmiş, vurgulanmıştır. Ayrıca bu yüklem öncelemeleri, ortaya çıkan sonuçların gerçekliğinin ve etkinliğinin bir kanıtı olma niteliğini de pekiştirmektedir. Bu nedenle çoğu -miş’li geçmiş kipindeki anlatımlarda (duyulan, belirsiz geçmiş), yüklemin anlattığı eylemin psikolojik bir yakınlık sağlayarak nesneyi (âşı̆̆ı) doğrudan etkilemesi söz konusu olmuştur. Böyle kullanımlarda genellikle -miş'li geçmiş kipindeki yüklemlerin sanki -di'li geçmiş zaman ( görülen, belirli geçmiş) gibi bir görünüşle (aspect) anlamı yansıtması zamana yeni boyutlar katmakta, dolayısıyla da algılanan etkinin kapsadığı alanı genişletmektedir.

Rüstem Paşa'nın veziriazamlığı üzerine Fuzulî’nin söylediği övgü kasidesinin (s. 82-85) 17 ve 18. beyitleri, Bağdat ve çevresinde ortaya 
çıkan yeni durumu ve gelişmeleri -miş'li geçmiş zamanlı yüklemlerle şöyle niteliyor:

Tâze gül-zâr-1 vezâretde açılmış bir gül

Virmiş âfâka nesîm-i eseri lutf-1 İrem

Kılmış andan bu safâ kesbini gül-zâr-1 vücûd

Olmış anunla bu bünyâd-1 letâfet muhkem (s. 83)

Öncelenmemiş olmakla birlikte 1. dizedeki açılmış eylemi ve öteki dizelerde öncelenen virmiş, kılmış, olmış eylemleri, bu türlü bir kullanımla Kaside içerisinde bir masal anlatımı izlenimi uyandırmaktan çok, ortaya çıkan yeni duruma herkesin tanık olduğu ve bu yeni durumun kanıtlarının herkesçe görüldüğü yargısını vermektedir. Nitekim bu beyitlerden sonra gelen beyitler (19-23), kanıtların kesinliği yargısını pekiştirmek üzere yüklemleri -di'li geçmiş zaman kipinde olan cümlelerle kurulmuştur.

Divan şiirinin "övgü sistematiği" içerisinde "övülen kişi"nin (memdûh) "çok küçük bir bağışının çok büyük sonuçlar doğurması" motifi, divan şiirinde türlü benzetmeler ve değiş̧ik imgelerle sik başvurulan bir anlatım yoludur. Fuzulî de bu Kaside'sinde Rüstem Paşa'yı "bahr, yem (deniz)" ve "kân (maden ocağı, kaynak)" ile karşılaştırarak "bağışlarının bolluğunu" koşut, yarı koşut, yinelemeli, karşıtlamalı, abartmalı, öncelemeli, sonlamalı bir geometrik söz yapısı içerisinde 34-37. beyitlerde şöyle anlatiyor:

Bahr ü kân eyleseler da'vi-i ihsân ammâ

Kerem ü cûdını gördükde olurlar mülzem

Kanı ol rütbe ki cûdıyla anun bahs ide bahr

Kanı ol havsala kim kân-ı keremden ura dem

Her ne tedrîc ile min yılda olur behre-i kân ${ }^{21}$

Her ne yüz yılda mürûr ile kilur hâsıl yem

21 “Olur behre-i kân" sözünün karşılığında TD'de "vire bahr ile kân” sözü bulunmaktadır. TD'deki bu varyantla beyte açık seçik bir anlam verebilmek zordur. Bu varyantın TD'de aparatta gösterilen 5 nüshadaki biçiminin doğru olduğu ve beyte daha kolaylıkla bir anlam verilebileceği kanısındayım. Önerdiğim bu varyantın doğruluğu, beytin koşut bir söz düzeni içerisinde söylenmiş dizeleri cümle öğeleri açısından düşey ilişkiler (paradigmatic relations) dikkate alınarak aşağıdaki 
Bezl bir demde ider meclisine hâzin-i cûd

Sarf bir günde k1lur bezmine kassâm-1 kerem (s. 84)

$\mathrm{Bu}$ dizelerde bahr/kân, kerem/cûd, cûd/bahr, kân/kerem, kân/yem, cûd/kerem anlam birimlerinin ikili bir söz düzeni içerisinde giderek yükselen bir tempoyla altışar kez yinelenerek, karşıtlanarak, oranlanarak Paşa'nın bağışının denizle karşılaştırılması gerçekten olağanüstü düzeyde bir abartı ortaya çıkarmaktadır. Kanı ol rütbe.../kanı ol havsala... sorularının, her ne ... min yılda /her ne yüz yılda sürelerinin ve bezl... ider/sarf... kılur eylemlerinin 6 dizede öncelenerek birbiri arkasına siralanması da "Paşa'nın bağışının çokluğu" ile "bahr'ın ve kân'ın verdiğinin azlığı (yokluğu)" arasındaki abartmayı bir kat daha güçlendirip pekiştirmektedir. "Kerem ü cûd" kavramlarının 34. beytin ikinci dizesinde öncelenmesi ile 37. beytin dizelerinin yine bu kavramlarla (cûd/kerem) sonlanması da bir rastlantı değildir. Fuzulî, şiirlerinde bu ve benzeri yapt-anlam ilişkilerini, üstün şairlik yeteneğinin ve sanatkâr yaratılışının $\left(t a b^{\prime}\right)^{22}$ doğal bir gereği olarak "bi'l-iltizâm" oluşturmaktadır.

Yukarıdaki -miş̧'li geçmiş kipindeki durum belirten yüklem öncelemelerinin bir benzeri, Bakî́nin bir kasidesinin matla ve hüsn-i matla beyitle-

biçimde kurallı cümle düzenine konulduğunda açık seçik olarak ortaya çıkmaktadır. Tersi durumda, yani TD'deki biçimle cümle nesnesiz (belirtili ya da belirtisiz) kalmaktadır. Zaten Fuzulî de, Rüstem Paşa'nın "kerem" ve "cûd"unun yanında "kân" ile "bahr"ın yetersiz kalacağını, yüzlerce yılda bile hiç bir şey (nesne) veremeyeceklerini söylüyor. Ayrıca, yukarıda belirtildiği gibi, söz konusu beyitlerin kuruluşuna ve kompozisyonuna egemen olan ikili söz düzeni de zaten bu yönde düşünmeyi ve yorumlamayı zorlamaktadır. Beytin dizeleri arasındaki koşutluk şöyle gösterilebilir:

Kân(ın) / / her ne/ / tedrîc ile/ / min yılda / / behre(si) olur

Yem / / her ne// mürûr ile// yüz yılda// hâsıl kilur

$\mathrm{Bu}$ örnek, beyitte yapılan düzeltme, önceleme ve koşutlukların, yineleme ve karşıtlıkların yalnızca "yazınsal değerler" açısından değil, "metin eleştirisi ve onarımı" açısından da ne denli önemli olduğunu gösteren çok güzel örneklerden birisidir. Bu konudaki daha geniş açıklama ve örnekler için bkz. Cem Dilçin, "Divan Şiirindeki Paralel ve Ortak Söz Yapılarından Metin Eleştirisinde Yararlanma", Türkoloji Dergisi, c. XIII, 1. sayı, Ankara 2000, s. 33-66.

${ }^{22}$ Tab' kelimesi yukarıda, Nef'î́nin şu ünlü beytinde (Dîvân 1252: Kas. s. 7) geçen anlamla kullanılmıştır:

Her ma'ni-i latîf ki cândan nişân virür

Ta'bîr idince tab`um anı nazma cân virür 
rinde (Küçük 1994: 24) sevgilinin güzelliğini betimleyen eylemlerle karşımıza çıkmaktadır. Eylemlerin sık kullanıldığı, bunlara türlü belirteçlerin eşlik ettiği, adlardan önce sıfatların getirildiği tasvirî üslûp uygulamaları açısından bakıldığında, Kaside'nin daha ilk beyitlerinde böyle öncelenmiş eylemlerin resimlendirmesiyle karşımıza renkli bir portre konulmakta ya da gözlerde bir doğa manzarası canlandırmaktadır:

Dökilmiş zülf-i müşg-âsâ o kadd-i dil-sitân üzre

Döşenmişs sâye-i Tûbâ bihişt-i câvidân üzre

Ten-i pâk-i arak-rîz olmış ol serv-i gül-endâmun

Dökilmiş katre-i şeb-nem nihâl-i ergavân üzre

\section{Kişi belirten yüklem öncelemeleri:}

$\mathrm{Bu}$ türlü öncelemelerde kişiler, genellikle konumu açısından taşıdığ önem ve konu içerisindeki rolleri nedeniyle ön plana çıkarılmıştır.

Fuzulî, 1534'te Bağdat'in fethi üzerine Kanuni Sultan Süleyman'a sunduğu kasidesinin (s. 45-50) nesip bölümünde Bağdat'1 "tavsif etmiş", daha önceleri o bölgeyle ilişkisi olmuş ya da o bölgede ve çevre ülkelerde yaşamış, bulunmuş, egemenlik sürmüş din, tasavvuf, devlet büyüklerinin, hatta, Leylâ ile Mecnûn, Ferhâd ile Şîrîn gibi mesnevi kahramanlarının adlarını da andıktan sonra (s. 45-46), dolaylı olarak tarihin geçmişlerinde kalmış o ulu ve ünlü kişilerin bu bölgeye daha önce "gelmiş" olduklarını, son olarak da "cihan padişahı" Kanuni Sultan Süleyman'ın "geldiğini" de 25. beytin 2. dizesinde kentin fetih tarihiyle $(\mathrm{H}$. 941) birlikte söyleyerek vurgulamıştır (s. 47). Bu tarih dizesinde "geldi" yükleminin öncelenmesi kesinlikle bir rastlantı değildir, yalnızca önce gelen/sonra gelen ilişkisini göstermek yani, pek çok ulu kişiye ve büyük sultanlara yurt olmuş o kutsal topraklara en sonunda Osmanlı padişahının da ayak bastığını somutlaştırmak içindir. Önce gelen/sonra gelen ilişkisini kurmak, bu ilişkinin tarihsel değerini ve önemini gösterebilmek için de Kaside'de 14 dizede (5, 6, 7, 8, 9, 10, 11 ve 13. beyitler, s. 45-46) 'burada, bu yerde' anlamındaki "munda" sözü ve türevleri öncelenmiştir. Söz konusu "geldi" öncelemeli dize, işte bu vurgulamaların karşı1lğında söylenmiştir. Bu vurgulamalarla Osmanlı padişahının oradaki eksikliği ve orada bir kurtarıcı olarak beklendiği anlatılmak istenmiştir. Nitekim Kanuni de Bağdat'a, Fuzulî́nin 23. beyitte belirttiği gibi “bayır 
olmuş mülke mi'mâr-1 hıred" ve "susamış gül-zâra ebr-i nev-bahâr" olarak gelmiştir:

Geldi Burc-1 Evliyâ'ya pâdişâh-1 nâm-dâr

$\mathrm{Bu}$ dize "gelinen yer"i değil "gelen kişi"yi ön plana çıkarmaktadır. Çünkü önemli olan "Bağdat'a Osmanlı padişahının gelişi” değil, "Osmanlı padişahının Bağdat'a gelişi"dir. Tarih dizesi, ebced hesabı dikkate alınmadan, Kaside'nin her hangi bir dizesi gibi aynı vezinde ve Kanuni'nin sırf Bağdat'a gelişini ve kenti onurlandırışını anlatmak amacıyla aşağıdaki biçimde de söylenebilirdi; ancak bu durumda "geldi" yüklem öncelemesiyle sağlanan "kişiye odaklanma" olgusundan eser kalmazd1:

Evliyâ Burcı'na geldi pâdişâh-1 nâm-dâr

Fuzulî̀nin Ayas Paşa'ya sunduğu Kaside'nin ilk 4 beyti de, gerçekten güzel bir yüklem öncelemesi ve tekrir sanatıyla başlamaktadır. Bu önceleme ve tekrir (yinelemeli önceleme), Ayas Paşa'nın vezaret verilerek 1545 'te Bağdat'a vali olarak atanmasını vurgulamak ve "gelişini" duyurmak işleviyle kullanılmıştır. İlk 4 beyit, "Geldi ol Îsî kim...", "Geldi ol Hızr-1 mübârek-pey kim..." , "Geldi ol Mehdî ki..." , "Geldi ol Âsaf ki..." biçiminde farklı kişiliklerdeki büyük önderlerin benzetmelik olarak yer aldığı aynı söz yapısı içerisinde çok görkemli, eski deyimle "tumturaklı" bir biçimde söylenmiştir. Bu yüce kişilerin kutsal, tarihsel ve kültürel bütün özelliklerinin Ayas Paşa'nın kişiliğinde toplanıp birbirini izleyen 4 beyitte "geldi..." öncelemesiyle verilmesi, insanı, sanki ayrı ayrı kişiler geliyormuş gibi güzel bir yanılsama içine düşürmektedir. Zaten "şiir dili"nin amacı da kişiyi böyle bir düşsel ortama çekmek, böyle bir imgesel alana götürmek değil midir?

Bu Kaside'deki "geldi" öncelemesinin yapıldığı 4 beyit, yukarıdaki Kanuni Sultan Süleyman için söylenmiş örnekten biraz farklı da olsa çok başarılı bir benzeridir. Bu beyitler şöyledir:

1 Geldi ol Îsî kim andandur hayât-1 ehl-i hâl Yohdur ansuz halk cisminde hayâta ihtimâl

2 Geldi ol Hızr-1 mübârek-pey kim ansuz bî-delîl Muztarib kalmışdı ehl-i fazl u erbâb-ı kemâl 
3 Geldi ol Mehdî ki salmışdı zamân-ı gaybeti Ikd-1 nazm-1 kişver-i İslâm'a bîm-i inhilâl

4 Geldi ol Âsaf ki kondurmışdı cünd-i şevketi Dâmen-i Mülk-i Süleymân'a gubâr-1 ihtilâl

Bu beyitler, benzetildiği ya da karşılaştırıldığı önderler açısından aynı kişinin farklı yönlerini vurgulamakta, gelen kişiyi halkın gözünde yüceltip kurtarıcı bir önder düzeyine çıkarmaktadır. Sevgilinin, bir hükümdarın ya da bir devlet büyüğünün bir meclise, bir kente, bir ülkeye gelişiyle olağanüstü olumlu, güzel birtakım olayların ve durumların ortaya çıkması motifi, "gelen kişi" nin benzetildiği Îsî, Hızr, Mehdî, Âsaf'ın kimlikleri ve kişiliklerinin çağrışım gücüyle birleştirildiğinde insan belleğinde geçmişin derinliklerine uzanan bir anı zenginliği yaratmaktadır. Her ne kadar bu beyitlerde Ayas Paşa'nın "geliş"i ön planda gösteriliyor ise de, arka planda adı geçen bu 4 kutsal kişinin "geliş"i sanki herkesin gözünde yeniden canlandırılmaktadır. "Geldi ol..." biçiminde ilk 4 beyitte arka arkaya yinelenen bu yüklem öncelemeleri bu özelliğiyle yoğunlaştırılmış bir anlatım öğesi olarak insan belleğinde bu yönde var olan verileri tetikleyerek zengin bir duygu ve düşünce ortamı oluşturmaktadır. Kişi belirten öncelemelerin örneklerinden aşağıdaki gazel matlainda olduğu gibi, dilek-emir yapısındaki "yahma" ve "tökme" yüklemleriyle sevgilinin "can yakması" ve "kan dökmesi"ne karşılık "âşı̆̆ın feryadı" ve "göz yaşları"nın doğuracağı sonuçlar anımsatılıyor:

Yahma cânum nâle-i bî-ihtiyârumdan sahın

Tökme kanum âb-1 çeşm-i eşk-bârumdan sahın (s. 347)

Bir gazelden alınan aşağıdaki beyitte de yine aynı kuruluştaki "çekme" yüklemiyle, "sevgilinin eteğini çekmesi"ne karşılık "âşıkların ellerinin Tanrı'ya yakarmak için açılması"nın dikkate alınması güzel bir karşıtlık içerisinde dile getirilmektedir:

Çekme dâmen nâz idüp üftâdelerden vehm kıl

Göklere açılmasun eller ki dâmânundadur (s. 209)

Yine bir gazel beytinde kişi belirten işlevle öncelenmiş "çekme" yüklemi "tabip"ten beklentileri dile getirmektedir. Buna bağlı olarak ikinci dizedeki sen/men zamirleriyle kurulan tabip/âşık ilişkisi de derd/çare arasındaki zıtlığı kişiler açısından pekiştirmektedir: 
Çekme zahmet çek elün tedbîr-i derdümden tabîb

Kim degül sen bildügün men çekdügüm bîmârlığ (s. 271)

Fuzulî̀nin bir rübaisinin aşağıdaki dizelerinde de sevgilinin uzun boyuyla görülmesi, "gördüm" ve "bahtum" yüklemleriyle âşığın ön plana çıkarılarak içine düştüğü acıklı durum gözler önüne getirilmektedir:

Gördüm seni elden ihtiyârum gitdi

Bahdum kadüne sabr u kararum gitdi (s. 519)

Bakî̀nin bir gazelinin matla beytinin dizeleri (Küçük 1994: 134) de, kişi belirtme amacıyla "açıl", "salın" eylemlerinin sevgiliyi ön plana çıkardığı dilek-emir öncelemesiyle başlamaktadır. Sevgiliye seslenilirken aynı zamanda gül, nesrîn, serv, sanavber kişileştirilerek, bu çiçeklerden beklenen eylemleri belirtmek için kullanılan "görsünler" yüklemi de, dize başlarında öncelenen "açll", "salın" eylemlerini zıtlık ve teklik/çokluk açısından pekiştirmektedir:

Açıl bâğun gül ü nesrîni ol ruhsârı görsünler

Salın serv ü sanavber şive-i reftârı görsünler

\section{Kavram belirten yüklem öncelemeleri:}

Bu türlü öncelemeler genellikle, kasidede ya da başka tür bir şiirde işlenen konuya ilişkin temel nitelikteki kavramlardan birini, bu kavramı anlatmak açısından çağrışım değeri yüksek olan bir "eylem"le önceleyerek söze başlama biçiminde karşımıza çıkmaktadır. Öncelenen "eylem"in şiirin konusu açısından simgesel bir nitelik taşıması ya da böyle bir anlam yüklenerek kullanılması, şiirin bellekte kalıcılığını destekleyen etkili ve güçlü bir öğe olarak işlev görür. Şiirin redifiyle, ilk beyitte öncelenen eylem arasında anlamsal bir ilişki de varsa eylemin söz konusu özelliği redif aracılığıyla bütün beyitlere yansıtılır. Böylece şair, çağrışım gücünün etkisinden yararlanarak öncelediği eylemle şiir okuruna belli bir yönde düşünme ve duygulanma alanı açar.

$\mathrm{Bu}$ konudaki örneklere geçmeden önce, "kavram belirten öncelemeler"in yukarıdaki açıklamalara bakarak yalnızca yüklemlerle yapıldığı sonucu çıkarılmamalıdır. Bu bölümde yazının konusu açısından böyle bir sınırlama yoluna gidilmiştir. Yoksa, şiirin konusuna ilişkin olmak 
koşuluyla özel adlar, cümle öğesi olan her tür kelime kavram yönünden her hangi bir özellik taşıyorsa öncelenmesinden daha doğal bir şey olamaz. Nitekim yazının daha önceki bölümlerinde, yüklem dışında kavram açısından beytin anlamını, şiirin konusunu kavrayıcı ve kapsayıcı nitelikteki başka kelime türlerinin öncelendiği örnekler de verilmişti.

"Saçmak" eyleminin yüklem olarak öncelenmesiyle başlayan ve Ali Şir Nevâî'nin bir gazeline nazire ${ }^{23}$ olarak söylenmiş Fuzulî́nin eşsiz na tı Su Kasidesi, kavram belirten yüklem öncelemelerinin en güzel, en yetkin bir örneğidir. Başka şairlerden verilen aşağıdaki örneklerde de görüleceği gibi "saçmak" kavramı, kasidelerde ve gazel beyitlerinde işlenen tema ve motiflerin temeli niteliğindeki bir eylem olarak seçilmiş, bu tema ve motiflerin işlevini pekiştirmek için de aynı şiir içerisinde gerektiği yerlerde yinelenmiştir. Fuzuli'nin beyti dışındaki örneklerde "(su) saçmak" eylemi ise "serpmek, dökmek, atmak, yağdırmak ..." kavramları açısından genellikle olumlu ya da zorunlu neden/sonuç süreçlerini belirtmek ve ortaya çıkan iyi, güzel sonuçları betimlemek için kullanılmıştır.

Fuzulî̀nin $n a^{\prime} t^{\prime} ı$ ın matlainda ise kısaca söylemek gerekirse temel düşünce, zıtlıkları, karşıtlıkları, olamazlıkları anlatmaktır. Bu beyitteki od/su, yanmak/saçmak ve su-saçmak/su-çâre kılmamak kavramları arasındaki birbiriyle çelişen yönleri vurgulamak için bundan daha uygun bir kurgulama düşünülemezdi. "Saçma" olumsuz emir kipindeki yüklemin öncelenerek "göz yaşının gönülde tutuşan ateşi" söndüremeyeceği, bunun imkânsızlığı ve bu işe kalkışmanın gereksizliği en güçlü bir biçimde anlatılmıştır:

Saçma ey göz eşkden gönlümdeki odlara su

Kim bu denlü dutuşan odlara kılmaz çâre su (s. 23)

Nevâî́nin gazelinin matlaı da (Kut 2003: 394) "saçmak" eyleminin öncelenmesiyle başlamaktadır:

Saçtı tirdin gül üze ol serv-i gül-ruhsâr su

Köymekim def'iga kıldı ot üze izhâr su

${ }^{23}$ Tahir Üzgör, "Su Redifli Şiirler ve Fuzulî’nin Su Kasidesi'nin Kompozisyonuna Dâir", İlmî Araştırmalar Dergisi, sayı 9, İlim Yayma Cemiyeti Yay., İstanbul 2000, s.239-248. 
Ahmed Paşa'nın Sultan Bayezit'e sunduğu 54 beyitlik Âb Kasidesi de "saçsa" yüklem öncelemesiyle (Tarlan 1966: 102-105) başlamaktadır:

Saçsa benefşe zülfine ol gül-'izâr âb

Şâmî gül-âb gibi olur müşg-bâr âb

12. beyitte "sal" öncelemesiyle birlikte ikinci dizenin başında "saç" bir kez daha yinelenir. Bu beyitte ayrıca "sal" ve "saç" kişi belirten öncelemelerle sevgiliye seslenilerek "sal" eyleminin "hâk", "saç" eyleminin de "su" üzerindeki etkileri çok güzel bir koşutluk içerisinde verilmiştir. Bu dilek-emir anlamındaki eylemler, koşut söz yapısıyla birlikte şiirsel söyleyişe etkin bir canlılık ve hareket kazandırmıştır:

Sal hâke sâyeni kim ola müşg-bû zemîn

Saç suya cür'anı kim ola şehd-bâr âb ${ }^{24}$

Aynı eylem 50. beyitte bir kez daha yinelenir:

Lutfun rebîi itmek içün rûzgârı zeyn

Saçdı riyâz-1 zihnüme ey şehr-yâr âb

Necatî'nin Şehzade Mahmut'a sunduğu Âb Kasidesi de "saçdı" yüklem öncelemesiyle (Tarlan 1963: 32-34) başlamaktadır:

Saçdı zemîne çün yine ebr-i bahâr âb

Kıldı cihân yüzini yine sebze-zâr âb

Necatî́nin beytinde, yukarıda söz konusu edilen $(-d \imath)+($ yine), (yine) $+(-d \imath)$ söz yapısının güzel bir örneği görülmektedir.

Yukarıdaki örneklerde geçen ortak kullanımların ya da benzeri koşutlukların birbirine nazire olduklarını ileri sürerek o yönde yorumlar yapmak bana göre çok yüzeysel bir yaklaşım olur. Bu örneklerde, redifi "âb" ya da "su" olmaları nedeniyle zengin bir çağrışım yoğunluğu olan "saçmak" eyleminin kavram açısından taşıdığ1 önem nedeniyle öncelenmesinden daha doğal bir şey olamaz.

${ }^{24}$ Ahmed Paşa'nın bu beytinin mazmûnunu daha sonra Fuzulî bir gazelinde şu biçimde dile getirmiştir:

Aks-i rûyun suya salmış sâye zülfün toprağa

Anber itmiş toprağun adın suyun ismin gül-âb (s. 151) 
Fuzulî’nin "hançer" redifli na'tı, (s. 25-27) doğal olarak "hançer"in görevini, işlevini belirten "çekmek" eyleminin öncelenmesiyle başlamaktadır. "Çekmek" eylemi ayrıca kasidenin 6, 24 ve 30. beyitlerinde de öncelenmiştir. Bunların dışında 7 beyitte $(3,10,19,20,21,25,26)$ daha birbirini pekiştirecek biçimde ayrıca yinelenmiştir.

Çeker bî-rahmlar yanında her sâat zebân hançer

Günâhum sâbit eyler ölmegüm hâtır-nişân hançer (s. 25)

Öncelemede kavram belirtmek açısından Tevfik Fikret'in, İstanbul'un tarihsel, siyasal, toplumsal, yaşamsal, kültürel... yönlerden özelliklerini, bunlara ilişkin birtakım olumsuzluklarını, sisli bir günün doğal ortamına uygun karamsar bir ruh durumu içerisinde anlattığ1 44 beyitlik ünlü Sis şiiri $^{25}$ şu beyitle başlamaktadır:

Sarmış yine âfâkını bir dûd-ı muânid,

Bir zulmet-i beyzâ ki pey-â-pey mütezâid.

Sis şiirinde başta adı olmak üzere, "sarmak" kavramıla doğrudan bir bağ kurularak şiirin konusu bu kavram çevresinde geliştirilmiştir. Zaten ilk beytin söz varlığı "âfâk" kelimesinin dışında, "sarmak" eyleminin ortaya çıkardığı olumsuz durumlar ve "sis" olgusunun nitelik ve nicelik açısından taşıdığı özelliklerin betimlendiği kelimelerden oluşmaktadır: Sis/sarmak/duman/(sis'in sıfatı olarak) direnen, kalıcı/(görüşü engellediği için) beyaz karanlık/sürekli artıp yoğunlaşan gibi. Bu söz varlığ1 daha sonraki beyitlerde de azalarak ya da nitelik değiştirerek sürmektedir. Bu nedenlerle şiirde söz konusu edilen "kaplamak, kuşatmak, tutmak, örtmek, çökmek, kapatmak, basmak, yayılmak..." kavramlarının simgesi olarak şiirin başında "sarmış" yüklemi öncelenmiştir. Her ne kadar şiirde, yukarıda belirtildiği gibi o yılların İstanbul'unun kimi olumsuz görünümleri sergileniyorsa da, arka plandaki bu olumsuzluklar1 örtüp gizleyen "sis"e ön planda yer verilerek bir anlamda onları görmemek ve göstermemek gibi bir ikilem arasında kalındığı seziliyor. Başka bir yönden bakıldığında önemli olan İstanbul'un taşı toprağı, dağı tepesi, Boğaz'ı Marmara'sı değil, bunların ufuklarını tutmuş olan koyu

${ }^{25}$ Şiirin, "kendi içinde incelenmesi" için bkz. ( Kaplan 1963: 104-110). 
bir "sis"tir ve "sis"in işlevini anlatan "sarmak" kavramıdır. Burada hemen bir deneme yapmak gerekirse, şiirin ilk dizesi yine aynı vezinde,

Âfâkını sarmış yine bir dûd-ı muânid

biçiminde söylenmiş olsaydı, öncelenen "âfâkını" sözüyle İstanbul kenti ön plana çekileceğinden yukarıda yapılan bütün değerlendirme ve yorumlar temelsiz ve dayanaksız kalacaktı. Ayrıca bu dizenin böyle olmasıyla, "sis" olgusuna bağlı olarak yaratılan imge ve çağrışımlarla ilişki kopar, şiirin kompozisyonundaki bütünlük de zayıflardı.

Fikret, kişileştirdiği İstanbul kentine 17. beyitte de "sarmak" eylemiyle yakın anlamlı olan "örtmek" eyleminin emir kipindeki çekimi "örtün" yinelemeli öncelemesiyle seslenir ve yine ayn beyti "örtün" dileğini bir kez daha vurgularken şiiri sonlandırır:

Örtün, evet ey hâile... Örtün, evet ey şehr;

Örtün, ve müebbed uyu, ey fâcire-i dehr!...

Daha yukarıda verilmiş $(-m \imath s ̧)+($ yine $)$, (yine $)+(-m \imath s ̧)$ biçimindeki formül, Sis şiirinin ilk beytinde öncelenen söz kalıbına uymaktadır. Bu söz kalıbı, daha önce bir çok kez karşılaşılmış ya da bir çok kez gerçekleşmiş bir olayın sürecini belirtmek için baş vurulan bir anlatım yoludur. Nitekim İstanbul'un "sis"i yüzyıllardır bilinen, yaşanılan bir olgudur. $\mathrm{Bu}$ söz kalıbıyla bu durumun eskiliğine ve sürekliliğine gönderme yapılarak insanların belleklerinde önceden yer etmiş anı ve deneyimlerine birtakım göndermeler yapılarak türlü çağrışımlar yaratılmıştır.

Metin dilbilimi açısından yaklaşıldığında iki beyitte 6 kez yinelenen "örtün" eylemiyle anlatılan dilek-emir, apaçık görüldüğü gibi şiirin başındaki "sarmış" eylemine bağlıdır ve semantik açıdan "sis"in kalkmasını değil, tam tersine sürmesini acı ve buruk bir duyguyla belirtmektedir.

Nazımda devriklemeler ve buna bağlı olarak da türlü öncelemelerde kafiye ve redifin belli bir oranda da olsa etkisi vardır. Aşağıda ana çizgileriyle sorunu tanıtabilmek amacıyla kısaca değinildiği gibi, vezinlerin de öncelemeler açısından şairleri bir ölçüde yönlendirdiği görülmektedir. Ancak bu görüşten şairlerin veznin, kafiye ve redifin tutsağı oldukları ya da bunların etkisinden kurtulamadıkları gibi bir sonuç çıkarılmamalıdır. Türkçe'nin fonetik özellikleri nedeniyle bazı kafiye harfleri kimi kip ve 
zamanları kullanmayı kısıtladığı gibi se, ha, zel, je, dad, tı, zı, ayn, fe gibi harfler de tümüyle olanaksız duruma getirir. Çekimli eylemlerin redif olarak kullanılabildiği ve bunlara uygun kafiyelerle yazılmış kaside ve gazellerdeki devriklemelerde her türlü önceleme yapılabilirse de bir bölümü önemsizdir. Ancak, yukarıda değinildiği gibi bunların çoğunluğu semantik ve stilistik açıdan çok ilginç özellikler taşır. Böyle sözdizimsel yapıdaki beyitlerin pek çoğunda şairlerin üstün şairlik yeteneklerini ve sanatkâr niteliklerini yansıtan çok ilginç öncelemeler yapılmıştır.

Örneğin, Fuzulî́nin nesip bölümünde "sürâhî" (şarap şişesi) betimlemesi yaptığı kasidesinin kafiye ve redifi beytin ad cümlesinin yüklemini oluşturmaktadır. Böyle durumlarda da şairler söz yapıları açısından çok güçlü örnekler yaratmayı kolaylıkla başarmışlardır. Bunların büyük bir bölümü "sehl-i mümtenî" denilebilecek türdendir. Kaside'nin matla beyti şöyledir:

Bu sürâhî meselâ bir sanem-i ra'nâdur

Ki dem-â-dem tarab-engîz ü neşât-efzâdur (s. 113)

Fuzulî̀nin bu Kaside'si aynı zamanda, "yüklem" dışındaki "kavram belirten önceleme"ler için güzel bir örnektir. "Bu sürâhî" öncelemesiyle betimlenen nesne (sürâhî kavramı) belirtilmiş, sonra, "sürâhî"nin benzetmeliği olarak kullanılan "serv" ve "şem" 2 . beyitte öncelenerek çok güzel bir koşut beyit içerisinde verilmiştir:

Serv tek kamet-i dil-cûyile uşşâk-firîb

Şem' tek pertev-i ruhsâr ile bezm-ârâdur

1. dizede "sanem-i ra'nâ" diye nitelenen "sürâhî"nin bu beyitte de sevgilinin sıfatları olarak kullanılan benzetmeliklerle bütünleştirilerek iki katmanlı bir çağrışım zenginliği sağlanmıştır. "Sürâhî" adının başına getirilen "bu" gösterme sıfatının görevi yalnızca "işaret etme" amaçlı değildir. "Bu" sıfatı, onun bir "şarap şişesi" olduğunu, "su şişesi" ya da "zeytinyağı şişesi" olmadığını belirleyen görevi yanında, betimlenen nesneyi değerlendiren, özelleştiren, seçkinleştiren... bir amaçla da kullanılmıştır.

Ayas Paşa'nın övgüsündeki bir kasideye Fuzulî şöyle bir öncelemeyle başlamıştır. Bu beytin 'nasıl' anlamındaki "ne" sıfatıyla başlaması (yüklemden önce öncelenmesi) ve cümlenin öteki öğelerinin de dizelerde koşut bir söz yapısı oluşturacak biçimde düzenlenmesi bir rastlantıyla açıklanamaz: 
Ne lutfdur yine kim buldı sebzeden gül-zâr

Ne feyzdür yine kim saldı bâğa bâd-ı bahâr (s. 66)

Kasidenin 2. ve 3. beyitleri de, 1 . beyitte söz konusu edilen ve baharın gelişiyle ortaya çıkan lutf/sebz, feyz/bâd bağıntısını, yani "lutf" ve "feyz" in nasıl bir nitelikle göründügünü anlatmakta, lutf/sebz, feyz/bâd kavramlarına bağlı olarak aralarındaki neden-sonuç ilişkilerini belirtmektedir. Bu anlatımı daha da açarsak, matlaın 1. dizesi 2. beyitle, 2. dizesi de 3. beyitle açıklanmıştır. Ayrıca bu beyitteki "lutf" ve "feyz" kelimelerindeki medler, öncelenen "ne" sıfatına bağlı olarak bu kavramların "çokluk"unu anlatan bir "abartma vurgusu" görevi de yapmaktadır:

2 Müzeyyen oldı hat-ı sebze ile rûy-i zemîn

Letâfet-i hat-1 sebz ile eyle kim ruh-1 yâr

3 Hicâb-1 gaybda her feyz-i Hak ki mahfi idi

Cihâna eyledi lutf-ı nesîm gül izhâr

'Nasıl' anlamındaki aynı "ne" sıfatının öncelendiği şu gazel beyti de yukarıdaki örneğe benzemekle birlikte biraz farklıdır. Yukarıdaki beyitte "lutf" ve "feyz"in nasıl olduğu, daha sonra gelen iki ayrı beyitte açıklanmasına karşılık, bu beyitte "gam"ın "şerbet"inin ve "ruh"un "sihr"inin nasıllığı eksilür/artar karşıtlığı içerisinde aynı dizelerde veriliyor:

Ne şerbetdür gamun kim içdügümce eksilür sabrum

Ne sihr eyler ruhun kim bahdugumca rağbetüm artar (s. 195)

Özellikle redifi kimi zaman da kafiyesi ad ya da eylem cümlesinin yüklemi olan kaside ve gazellerde, söz dizimsel yapıları gereği olarak birden çok cümleden oluşmuş az sayıdaki beyitlerin dışında, yüklem öncelemelerine çok az rastlanır. Bu türlü kaside ve gazellerde kimi ortaç ve ulaçlar dize başlarında yer alsa da, bunların her beyitte anlamsal açıdan etken olan bir öncelik değeri taşıdığı söylenemez. Redifi yüklem olan cümlelerde doğal olarak anlaşılacağ öncelenir. Yukarıda, "yine" belirtecinin az sayıda örnekle en belirgin yönleri üzerinde kısaca durularak önemi belirtildiği gibi, yüklem d1şında öteki cümle öğelerinin ele alınarak stilistik açıdan değerlendirilmeleri divan şiirinin "yazınsal değerleri"ne ve divan şairlerinin sanatçı kişiliklerine önemli katkılar sağlayacaktır.

Yüklem öncelemelerinde fiil kiplerinin belirlenmesinde anlamin ve anlatımın yanı sıra kimi zaman vezin de etkili olabilmektedir. Ancak 
bunu bir zorunluluk olarak algılamamak gerekir. Veznin açık ve kapalı hecelerinin düzeni açısından bir olanaksızlık doğduğunda şair başka bir cümle öğesini önceleyebilir ya da eylemin hecelerinde aruz kuralları içerisinde imale, med, vasl yaparak uygun fiil kipi kullanabilir. Unutulmamalıdır ki şiir "dili kullanma sanatıdır", yani "şiir söyleme" her hangi bir "söz söyleme" değildir. Çünkü metin (text), manzum olsun mensur olsun bütün söz, anlam ve deyiş ölçütleri göz önüne alınarak oluşturulan bir "söz dokuması", bir "söz örgüsü"dür. İplik has ipekten de olsa, özenle dokunmamış, düzenle örülmemiş ise kumaşın güzelliğinden söz edilemez.

Kesin bir genelleme yapılamazsa da örneklerin incelenmesinden yüklem öncelemelerinde bazı yüklem kiplerini ve eylem çekimlerini veznin yönlendirdiği izlenebilmektedir. Daha açık söylemek gerekirse, kapalı heceyle başlayan vezinlerde kapalı, açık heceyle başlayan vezinlerde de açık heceyle başlayan fiil çekimlerinin öncelendiği bir kural olmamakla birlikte görülebilen ve izlenebilen bir uygulamadır. Örneğin, fâilâtün ya da feilâtün tef'ileleriyle başlayan vezinlerde sıklıkla -di'li geçmiş zaman, mefâîlün tef'ilesiyle başlayan vezinlerde geniş zaman, mef'ûlü tef'ilesiyle başlayan vezinlerde -miş̧'li geçmiş zaman ve emir kipi, mefâilün tef'ilesiyle başlayan vezinlerde işteş ve edilgen çatılı fiil çekimlerinin kullanıldığı görülmektedir. Bunlara koşut olarak, yukarıdaki vezinlerin ilk tef'ilelerine uyan zarf fiillerin ve sıfat fiillerin kullanım sıklı̆̆ da oldukça yüksektir. Ancak, kimi eylem kiplerinin türlü çekimleri aç1sindan aruzun tef'ilelerine uymadığı da bilinen bir gerçektir. Bu nedenle bu türlü çekimlenmiş eylemlerin örneklerine divan şiirinde pek rastlanmaz.

Yukarıda belirtilen en belli başlı uygulamaların örneklerini ve benzerlerini çok yaygın olmamakla birlikte divan şiirinin her türünde gözlemlemek olanağı vardır. Bunlardan, vezinleri yalnızca mefâilün feilâtün mefâilün feilün (.-.-/..--/.-.-/..-) vezniyle yazılmış Fuzulî́nin, Bakî'nin ve Nef'î́nin birer kasidesinden veznin ilk tef'ilesine uygun çekimlerde yapılmış yüklem öncelemeleri ve "fiilimsi"lerden örnekler şöyledir:

Fuzulî́nin 92 beyitlik Tevhîd Kasidesi'nde (s. 15-92) edilgen çatılı fiil çekimlerinin ya da veznin açık kapalı hece sırasına (.-.-) uyan fonetik yapıdaki benzerlerinin öncelendiği yüklem örnekleri: Yazıldı (2 kez), 
çekildi, bilindi, görindi, boyandı, bırahdı, götürdi (2 kez), kılurdı (2 kez), olurd, iderdi, olınca.

Bakî̀nin Kubâd Paşa için "hilâl vasfında" söylediği 47 beyitlik kasidesinden (Küçük 1994: 49-52) örnekler: Takındı, takıldı, sarındı, sokındı, tolaşdurur, götürdi, yazılmaya, boyandı, güzellenüp, koyınca.

Nef'î́nin IV. Murat'ın övgüsünde söylediği 53 beyitlik bir kasideden (Dîvân 1252: Kas. s. 48-50) örnekler: Asıldı, çalındı, yetişdi, döşendi, dikildi, unutdurur, komazdı, çekerdi, bulurdı, iderdi, virirdi, olaydı, çekilse, iderse, getirdi, olursa (2 kez), göreydi, sunınca, çekince, sürince, yazınca, gelince (2 kez), olınca.

Yukarıda gösterilen yüklem ve fiilimsi örneklerinin beyit sayıları verilen kasidelerdeki kullanım sıklı̆̆ına bakılarak sayıca az görülmemelidir. Çünkü, kasidelerde öncelenmiş öteki fiil çekimleri, kelime türleri ya da cümle öğeleri açısından yüzdeye vurulduğunda yukarıdaki örneklerin daha yüksek çıkacağı açık bir gerçektir. Bunun yanı sıra şu gerçeği de belirtmek gerekir ki, kasidelerin başka beyitlerinde yukarıdaki örneklerin benzeri olan, metnin yapısal bütünlüğünü sağlayan, anlatımı pekiştiren, söz konusu öncelemeleri destekleyen, ancak öncelenmemiş başka yüklem örnekleri varsa da bunlar konunun dişındadır.

Yapısal açıdan sağlam bir bütünlük gösteren Bakî'nin mef'ûlü fâilâtü mefâîlü fâilün (--./-.-./.--./-.-) veznindeki Kanuni Sultan Süleyman Mersiyesi'nin (Küçük 1994: 75-81) doğayı ve canlı cansız bütün varlıkları hep birlikte yas tutmaya çağıran III. ve IV. bentlerinin veznin iki kapalı başlayan ilk tef'ilesine (--.) uygun kimi dilek-emir kipindeki öncelenmiş yüklemleri şöyledir: Döksün, itsün, kılsun, geysün, yaksun, olsun (2 kez), tutsun. Bu yüklemlerle anlatılan kavramları pekiştiren aynı bentlerdeki ve bunları izleyen $\mathrm{V}$. bentteki öncelenmemiş benzeri dilek-emir kipindeki yüklem örnekleri de şunlardır: Olsun, tutsun, gezsün, çz̈zsün, döksün, tutsun, çeksün, girsün (2 kez), batsun..

Yine doğayı, canlı cansız bütün varlıkları işlevlerini yapmayarak ölen için yas tutmaya çağıran anlatımlara başka mersiyelerde de rastlanmaktadır. Ancak aşağıda verilen öncelenmiş yüklem örnekleri yukarıdakilerin tersine, şiirde kullanılan vezin gereği olarak ayn dilek-emir kipinin olumsuzu biçiminde karşımıza çıkmaktadır. Bu örnek, benzeri duygu ve düşünceleri dile getirirken şairlerin veznin ezgilerine göre 
deyişlerini nasıl kendilerine özgü ölçütlerle belirlediklerini gösteren ilginç bir örnektir. Nergisî́nin Kaf-zâde Fâizî için feilâtün feilâtün feilâtün feilün (..--/..--/..--/..-) vezninde söylediği Mersiye'nin (İsen 1993: 234-237) ilk bendinde, veznin tef'ilelerine uygun olarak şu yüklemleri öncelemiştir: Dönmesün (çarh-1 felek), toğmasun (mâh-1 cihân), esmesün (bâd-1 sabâ), yağmasun (nîsân-1 amânî), girmesün (zemzeme-i şevk ü sürûr).

Mersiye türünde, ölen kişi için doğa ve bütün varlıklara yapılan "yas tutma çağrısı"nın anlatımında aynı eylem kipinin (dilek-emir) olumlu ve olumsuz çekiminin öncelenerek kullanımının örneğini karşılaştırabilmek amacıyla Bakî ve Nergisî'den birer beyti buraya aktarıyorum:

Kilsun kebûd câmelerin âsmân siyâh

Geysün libâs-1 mâtem-i Şâh'1 bütün cihân

Nergisî́nin Mersiye'sinin ilk beyti:

Dönmesün çarh-1 felek hâk ile yeksân olsun

Toğmasun mâh-1 cihân ol dahi pinhân olsun

Fuzulî’nin şiirlerinden daha çok münâcât konulu birkaç gazelinde örneğine rastladığımız benim "gizli önceleme" adını verdiğim bir anlatım yolunu da burada söz konusu etmeden geçemeyeceğim. Divan ve Leylâ vü Mecnûn'daki bir iki münâcât konulu gazelinde bu "gizli ünlem öncelemesi" karşımıza çıkmaktadır. Aşağıda matla ve makta beyitleri verilen iki gazelin, ilk ve son dizeleri "Yâ Rab" öncelemesiyle başlamaktadır. Fuzulî, bu gazellerinin matla ve makta dişındaki beyitlerini de, sanki "Yâ Rab" ünlemi öncelendiğinde anlamlı olabilecek bir sözdizimsel yapı içerisinde düzenlemiştir. Böyle bir düzenlemeyle bu beyitlerde Tanrı'ya karşı dile getirilen yalvarma ve yakarışlar, insanın bütün benliğini saran bir derinlik ve yoğunlukla algılanmaktadır. Bu açık ve gizli öncelemelerin yanında, gazelin böyle bir derinlik ve yoğunluk kazanmasında başka stilistik özelliklerin katkısı da vardır. İlki Divan'ında ötekisi de de Leylâ vü Mecnûn'da olan söz konusu iki gazelin matla ve makta beyitleri şöyledir:

Yâ Rab hemîşe lutfunı kıl reh-nümâ mana

Gösterme ol tarîkı ki yitmez sana mana 
Habs-i hevâda koyma Fuzulî-sıfat esîr

Yâ Rab hidâyet eyle tarîk-1 fenâ mana (s. 127)

"Mecnun dilinden" söylenmiş gazelin ilk ve son beyitleri (Onan 1956: 113-114):

Yâ Rab belâ-yı 1şk ile kıl âşnâ meni

Bir dem belâ-yı 1şkdan itme cüdâ meni

Nahvet kılup nasîb Fuzulî kimi mana

Yâ Rab mukayyed eyleme mutlak mana meni

Fuzulî’nin pek çok beyitte bunlar ve benzeri biçimlerde gerçekleştirdiği "söz mimarisi"ne hayran olmamak mümkün değildir.

Yukarıda çok kısa açıklamalarla bir iki türüne değindiğim ve bunları kanıtlayacak pek az örneğini verdiğim öncelemeler, divan şiirinin ve şairlerinin sanat ve sanatçı yönünü ince çizgilerle ortaya koyabilmek açısından, yapılması gereken stilistik çalışmaların ne denli gerekli ve ne ölçüde zorunlu olduğunu sanırım apaçık göstermektedir.

\section{KAYNAKÇ A}

Ahmed Âsım, Okyânûsü'l-Basît fî̀-Tercemeti'l-Kamûsi'l-Muhît, c. 1, İstanbul 1268 (1851).

Ahmet Vefik Paşa, Lehce-i Osmânî, Haz. Recep Toparlı, TDK Yay., Ankara 2000.

Akyüz, Kenan (1970), Batı Tesirinde Türk Şiiri Antolojisi, 3. bas., Ankara.

Banguoğlu, Tahsin, Türkçenin Grameri, TDK Yay., 3. bas., Ankara 1990.

(Beyatlı), Yahya Kemal (1963), Kendi Gök Kubbemiz, Yahya Kemal Enstitüsü Yay., 2. bas., İstanbul.

(Boztepe), Halil Nihat, Nedim Divan, İstanbul 1338-1340/1919-1921.

Dilçin, Cem, "Ahmed Paşa'nın Şiirlerinde Paralelizm", İstanbul'un Fethinin 550. Yilı Amı Kitabı, DTCF Yay., Ankara 2004, s. 55-72.

Dilçin, Cem (2005), Örneklerle Türk Şiir Bilgisi, TDK Yay., 8. bas., Ankara.

Dilçin, Cem, "Divan Şiirindeki Paralel ve Ortak Söz Yapılarından Metin Eleştirisinde Yararlanma", Türkoloji Dergisi, c. XIII, 1. sayı, Ankara 2000, s. 33-66.

Dîvân-ı Nef'î (1252/1836), Misır-Bulak.

Dizdaroğlu, Hikmet (1976), Tümcebilgisi, TDK Yay., Ankara. 
Ergun, Sadettin Nüzhet (1941), Namık Kemal'in Şiirleri, İnkılap Kitabevi, İstanbul.

Fomkin, Mihail Simyonoviç, "Sultan Veled (1226-1312)'in Şiir Sanatı ve Türk Şiir Geleneği", Türk Dili Araştırmaları Yıllı̆̆ı-Belleten 1991, TDK Yay., Ankara 1994, s. 137-148.

Fuzîlî, Türkçe Divan (TD), (Haz. Kenan Akyüz, Süheyl Beken, Sedit Yüksel, Müjgân Cunbur), Türkiye İş Bankası Kültür Yay., Ankara 1958.

Gencan, Tahir Nejat (1979), Dilbilgisi, TDK Yay., 4. bas., Ankara.

Göçgün, Önder (1987), Ziya Paşa'nın Hayatı, Eserleri, Edebi Şahsiyeti ve Bütün Şiirleri, Kültür Bakanlığı Yay., Ankara.

Gölpınarlı, Abdülbâki (1972), Nedim Divanı, İnkılap ve Aka Kitabevleri, 2. bas., İstanbul.

Güngör, Şeyma, Fuzulî, Hadîkat's-Sü'edâ', Kültür ve Turizm Bakanlığı Yay., Ankara 1987.

İsen, Mustafa (1993), Acıyı Bal Eylemek, Türk Edebiyatında Mersiye, Akçă̆ Yay., Ankara.

Kaplan, Mehmed (1963), Şiir Tahlilleri, Âkif Paşa'dan Yahya Kemal'e Kadar I, Anil Yay, 3. bas., İstanbul.

Kortantamer, Tunca, Eski Türk Edebiyatı Makaleler-I, Akçağ Yay., Ankara 1993.

Kut, Günay (2003), Alî Şîr Nevâŷ̂, Garâ'ibü's-Sıgar, Inceleme-Karşılaştırmalı Metin, TDK Yay., Ankara.

Küçük, Sabahattin (1994), Bâkî Dîvânı, Tenkitli Basım, TDK Yay., Ankara.

Ocak, Fatma Tulga, "Nef'î ve Eski Türk Edebiyatımızdaki Yeri", Ölümünün Yüzellinci Yılında Nef'î, Atatürk Kültür Merkezi Yay., Ankara 1987, s.1-44.

Olgun, Tahir, Edebiyat Lügati, İstanbul 1937.

Onan, Necmettin Halil (1956), Fuzuli, Leylâ ile Mecnun, MEB Yay., İstanbul.

Tarlan, Ali Nihad (1963), Necatî Beg Divanı, MEB Yay., İstanbul.

Tarlan, Ali Nihad (1966), Ahmed Paşa Divanı, MEB Yay., İstanbul.

Türkçe Sözlük, TDK Yay., 10. bas., Ankara 2005.

Ünsal, Özünlü (1997), Edebiyatta Dil Kullanımları, Doruk Yay., Ankara.

Üzgör, Tahir, "Fuzûlî’yi Anlamak", Selçuk Üniversitesi Türkiyat Araştırmaları Dergisi, say1 3, Konya 1997, s. 87-101.

Üzgör, Tahir, "Su Redifli Şiirler ve Fuzulî’nin Su Kasidesi'nin Kompozisyonuna Dâir", İlmî Araştırmalar Dergisi, sayı 9, İlim Yayma Cemiyeti Yay., İstanbul 2000, s.239-248. 